\title{
Standardized ileal digestible lysine requirement for broilers
}

\author{
J.W. Spek \\ Wageningen Livestock Research
}

CVB Documentation report nr. 62

June 2018

Wageningen Livestock Research

P.O. Box 338

$6700 \mathrm{AH}$ Wageningen

The Netherlands 


\section{(c) Federatie Nederlandse Diervoederketen 2017}

No part of this edition may be copied, photocopied, reproduced, translated or reduced to any electronic medium or machine-readable form, in whole or in part, without specific written permission of the Federatie Nederlandse Diervoederketen (info@diervoederketen.nl).

All copyrights and database rights with respect to this publication are expressly reserved. Nothing in this publication may be reproduced, copied, retrieved, made public or re-used or made available in any way whatsoever to third parties by way of printing, photocopying, microfilm or in any other way unless the Federatie Nederlandse Diervoederketen has given express written permission to do so. This publication has been compiled with great care; however, the Federatie Nederlandse Diervoederketen and Wageningen Livestock Research cannot be held liable in any way for the consequences of using the information in this publication. 


\section{Preface}

In 2017 a new Table has been introduced called; Table 'Standardized ileal digestibility of amino acids in feedstuffs for poultry' and has been described in the CVB Documentation report nr. 61 . As a feed evaluation system has two pillars - the supply of nutrients by the diet on the one hand and the requirement for these nutrients by the animals on the other hand (both expressed in the same units) - it was also necessary to also update and express the amino acid requirements on a standardized ileal digestibility (SID) basis.

Therefore a large meta-analysis dataset was constructed from studies in which amino acid requirements in broilers were estimated. The SID amino acid concentrations of the diets used in these studies were recalculated based on the new CVB SID amino acid Table presented in CVB documentation report nr. 61 and the requirements for SID lysine were subsequently estimated. The results of this meta-analysis for standardized ileal digestible lysine (SID-LYS) are presented in the present CVB Documentation report. Compared to the former CVB apparent faecal digestible LYS recommendation for broilers described in CVB Documentation report nr. 18 and published in 1996 the present established SID-LYS amino acid recommendations for broilers are:

1. Based on a substantial larger dataset of requirement studies

2. Based on studies with modern broiler types in the period $1990-2017$

3. Based on standardized ileal digestible amino acid values in feedstuffs instead of apparent faecal digestible amino acid values.

The in this report estimated requirement of SID-LYS will be incorporated in the Dutch CVB Tabellenboek Veevoeding Pluimvee 2018 and in the English version CVB Table Poultry Nutrition 2018.

This study was guided and assessed by the Technical Committee of CVB

Wageningen, June 2018

J.W. Spek 


\section{Members of the Technical Committee of the CVB}
M. Rijnen (chair)
J. Fledderus
B. Boswerger
A. Dijkslag
H. van Laar
K. Geerse
D. van Manen
J. van der Staak
H. Korterink
A. van de Ven
C. van Vuure
G. van Duinkerken

J.W. Spek
Nederlandse Vereniging Diervoederindustrie (Nevedi) Nederlandse Vereniging Diervoederindustrie (Nevedi) Nederlandse Vereniging Diervoederindustrie (Nevedi) Nederlandse Vereniging Diervoederindustrie (Nevedi) Nederlandse Vereniging Diervoederindustrie (Nevedi) Nederlandse Vereniging Diervoederindustrie (Nevedi) Overleggroep Producenten Natte Veevoeders (OPNV) Land- en Tuinbouworganisatie Nederland (LTO) Nederlandse Vereniging van Handelaren in Stro, Fourages en Aanverwante Producten (HISFA) Nederlandse Vereniging Diervoederindustrie (Nevedi) MVO, ketenorganisatie voor oliën en vetten Wageningen Livestock Research, Dept. Animal Nutrition, Wageningen

Wageningen Livestock Research, Dept. Animal Nutrition, Wageningen 


\section{Contents}

Table of Contents $\quad$ Page

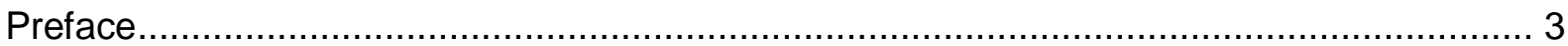

Members of the Technical Committee of the CVB …...................................................... 4

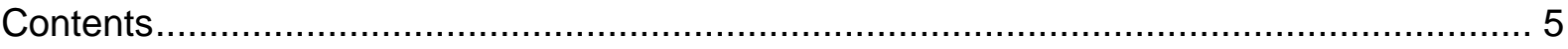

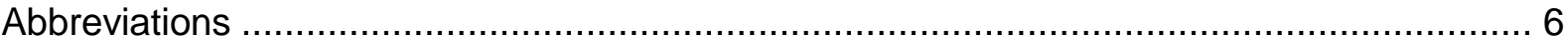

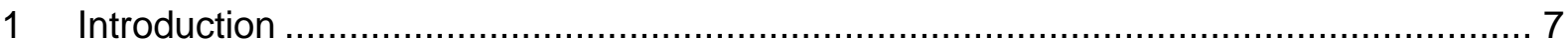

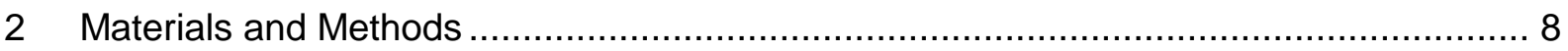

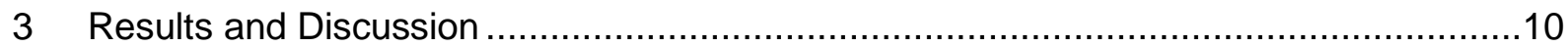

3.1 Estimation of SID-LYS requirements for maximum BWG ...............................11

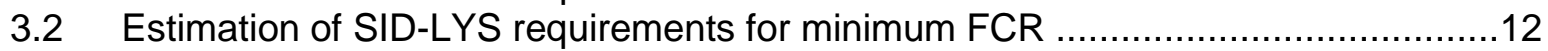

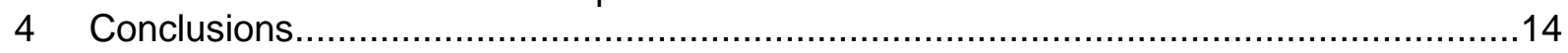

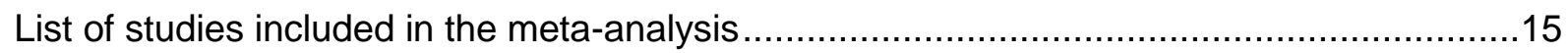

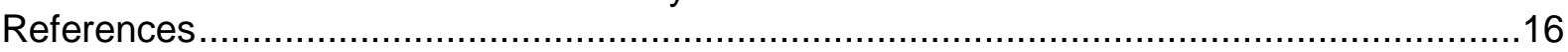

Appendix A. Relationship between dietary SID-LYS supply and performance parameters FCR and BWG for the various titration trials including the estimated SID-LYS requirements based on the linear broken-line model, the quadratic brokenline model and the exponential model.....................................................17

Appendix B. SID-LYS model estimates using the quadratic broken-line model for minimum FCR and maximum BWG 


\section{Abbreviations}

$\begin{array}{ll}\text { AA } & \text { Amino acids } \\ \text { AFD } & \text { Apparent faecal digestible } \\ \text { ARG } & \text { Arginine } \\ \text { BWG } & \text { Body weight gain } \\ \text { CP } & \text { Crude protein } \\ \text { FCR } & \text { Feed conversion ratio } \\ \text { ILE } & \text { Isoleucine } \\ \text { LYS } & \text { Lysine } \\ \text { ME } & \text { Metabolic energy } \\ \text { MEbr } & \text { Metabolic energy for broilers } \\ \text { MEpo } & \text { Metabolic energy for poultry } \\ \text { MET } & \text { Methionine } \\ \text { M+C } & \text { Methionine plus Cysteine } \\ \text { N } & \text { Number } \\ \text { R } & \text { Coefficient of determination } \\ \text { Req } & \text { Requirement } \\ \text { SID } & \text { Standardized ileal tract digestible } \\ \text { Std. Dev. } & \text { Standard deviation } \\ \text { Std. Err. } & \text { Standard error } \\ \text { THR } & \text { Threonine } \\ \text { TRP } & \text { Tryptophan } \\ \text { VAL } & \text { Valine }\end{array}$




\section{Introduction}

In 2012 a large meta-analysis was carried out by Veldkamp and others in order to determine the dietary requirements for standardized ileal tract digestible (SID) amino acids (AA) for broilers. This study resulted in a report published by Veldkamp et al. (2016). Before the start of this meta-analysis another large meta-analysis was carried out in order to determine the SID-AA levels for the various feed ingredients. This meta-analysis resulted in a CVB table with SID-AA concentrations for the various feed ingredients and this Table was used by Veldkamp et al. (2016) in order to recalculate the dietary SID-AA levels for the individual AA titration studies in order to estimate AA requirements. However, in 2017 this CVB Table has been updated with new data published in the years between 2012 and 2017 as there were questions about the SID cysteine digestibility value for soybean meal. As a result, not only the SID-AA values for soybean meal have been updated but also for other feedstuffs. As a consequence it was necessary to recalculate all the diets used in the AA titration studies that Veldkamp et al. (2016) used to determine AA-requirements. In this study the results of estimated dietary SID lysine (SID-LYS; \%) requirements based on the new Table values are presented. Furthermore, the dataset used by Veldkamp et al. has been extended with new studies that were not included in the study of Veldkamp et al.. This resulted in a dataset more than twice as large as the dataset used by Veldkamp. Furthermore, multiple models for estimation of SID-LYS requirements have been used and compared with each other in this study such as the exponential model as described and used by Veldkamp et al. (2016), a linear broken-line model and a quadratic broken-line model. 


\section{Materials and Methods}

Lysine titration studies were selected from literature $(1990-2017)$ in which only the dietary LYS content was varied by means of addition of graded levels of dietary synthetic LYS.

Furthermore, only those titration studies were selected in which non-test apparent digestible LYS levels of the basal diet (diet with the lowest LYS content) were less than $10 \%$ of the recommended CVB (2012) levels and where dietary digestible LYS levels of the basal diets where at least $20 \%$ below the recommended CVB (2012) level. Furthermore, performance characteristics such as body weight gain (BWG: $g / d$ ) and feed conversion ratio (FCR; $g$ feed : $g$ BWG) had to be recorded and information with respect to dietary composition, sex, age of the broilers and duration of the experiment had to be provided in the studies.

Requirements were estimated using three models, an exponential model, a linear broken-line model and a quadratic broken-line model.

The exponential model is as follows:

$\mathrm{Y}=\mathrm{a}+\mathrm{b}^{*}\left(1-\mathrm{e}^{\left(-\mathrm{C}^{*} \mathrm{dx}\right)}\right)$

Where: $Y=$ response value of $B W G$ or $F C R$;

$\mathrm{a}=$ estimated basal level (for $\mathrm{dx}=0$ ) of the amino acid LYS;

$b_{i}=$ difference between basal level and estimated asymptotic level for BWG or FCR response;

$\mathrm{C}=$ rate parameter (for speed of curving);

$\mathrm{dx}=$ difference in LYS concentration compared to the basal (non-supplemented) diet;

For each individual experiment the estimated requirement (Req) for the amino acid of interest was calculated as the amino acid concentration where $95 \%$ of the response (BWG and FCR) between intercept and asymptotic value was reached. The estimated amino acid requirement was calculated by the following mathematical equation:

$\operatorname{Req}=\frac{\ln (0.05)}{-c}+\operatorname{MIN}(\mathrm{Xi})$

Where:

Req = Estimated amino acid requirement (\%) of the individual experiment;

$\operatorname{Ln}(0.05)={ }^{e} \log (0.05) ;$

$\mathrm{C} \quad=$ rate parameter (for speed of curving);

$\operatorname{MIN}\left(X_{i}\right)=$ amino acid (\%) in basal (non-supplemented) diet

The linear broken-line model is as follows:

If $(S I D-L Y S(g / k g)<R)$ then BWG or FCR $=L+U \times(R-S I D-L Y S)$;

Else BWG or FCR $=\mathrm{L}+\mathrm{U} \times 0$;

Where:

$L=$ plateau value for BWG or FCR

$\mathrm{R}=$ break-point value for SID-LYS $(\mathrm{g} / \mathrm{kg})$

$\mathrm{U}=$ slope value, representing the increase in BWG or decrease in FCR per unit increase in dietary SID-LYS. 
The quadratic broken-line model is as follows:

If $(S I D-L Y S(g / k g)<R)$ then BWG or FCR $=L+U \times(R-S I D-L Y S)^{\wedge}$;

Else $B W G$ or $F C R=L+U \times 0$;

Where:

$L=$ plateau value for $B W G$ or $F C R$

$\mathrm{R}=$ break-point value for SID-LYS $(\mathrm{g} / \mathrm{kg})$

$\mathrm{U}=$ slope value, representing the increase in BWG or decrease in FCR per unit increase in dietary SID-LYS.

For a number of titration studies a clear decrease in feed intake was observed after an initial increase in feed intake at increased levels of dietary LYS suggesting that the increase in dietary LYS after a certain optimum level resulted in a negative feedback on feed intake. This decrease in feed intake at increased LYS levels after a certain optimum LYS level for feed intake and performance has been achieved may affect the estimation of the optimal SID-LYS level. Therefore, SID-LYS requirements were also estimated after excluding the observations with these lower feed intakes. A lower feed intake was considered 'lower' as the feed intake of the two preceding dietary LYS levels were higher than the highest LYS level. However, in some cases this resulted in estimated 'extrapolated' SID-LYS requirements that were higher than the highest SID-LYS level. Therefore it was decided to only estimate SID-LYS requirements based on all the data.

Via the PROC MIXED procedure and the PROC NLMIXED procedures of SAS estimated SID-LYS requirements for BWG and FCR were regressed against factors such as age, sex, the dietary factors $C P, M E$ and $C P$ : ME ratio with study effect included as a random factor. Furthermore, the estimated SID-LYS requirement levels were also used to calculate ratios of other non-test SID-AA with the estimated requirement SID-LYS levels and it was checked whether some of the non-test SID AA were negatively affecting the estimated SID-LYS levels. 


\section{Results and Discussion}

In Table 1 a summary of the total dataset is given. The dataset consisted of 19 studies with in total 54 titration trials and 317 observations. In all 19 studies maize was the principal feed component.

Table 1. Summary of the total dataset

\begin{tabular}{lrrrrr}
\hline & N & Mean & $\begin{array}{r}\text { Std. } \\
\text { Dev. }\end{array}$ & Minimum & Maximum \\
\hline MEpo Recalculated (kcal/kg) & 317 & 3034 & 111.9 & 2635 & 3152 \\
ME Publication (kcal/kg) & 317 & 3168 & 128.8 & 2700 & 3370 \\
CP Recalculated (\%) & 317 & 20.6 & 1.45 & 17.8 & 23.2 \\
CP Publication (\%) & 317 & 20.4 & 1.55 & 17.2 & 23.6 \\
Year & 317 & 2006 & 4.3 & 1999 & 2012 \\
Starting age (d) & 317 & 11 & 9.5 & 1 & 35 \\
Duration (d) & 317 & 16 & 4.3 & 6 & 25 \\
finishing age (d) & 317 & 27 & 10.9 & 7 & 49 \\
Mean age (d) & 317 & 19 & 10.0 & 4 & 42 \\
BWG (g/d) & 317 & 52.7 & 30.52 & 15.8 & 189.3 \\
FCR (g feed: g growth) & 317 & 1.605 & 0.2425 & 1.029 & 2.644 \\
\hline
\end{tabular}

In Appendix A for each titration trial the relationship between dietary SID-LYS supply and FCR and between dietary SID-LYS and BWG is presented graphically together with the estimated SID-LYS requirements for the exponential, linear broken-line and quadratic broken-line models. A visual analysis of these graphs show that in most cases the estimated SID-LYS requirements using the linear broken-line model is lower than the SID-LYS concentration at which maximum BWG or minimum FCR is observed and also that in a number of cases the estimated SID-LYS requirements using the exponential model is substantially overestimating the requirement for SID-LYS. Furthermore, the root of the squared difference between the estimated SID-LYS requirements and the observed SID-LYS requirements at which minimum FCR was observed or maximum BWG was observed was smallest for the quadratic broken-line model (the average squared root difference between estimated SID-LYS requirements and the observed SID-LYS requirements for FCR was an absolute $0.0677 \%$ for the quadratic broken-line model compared to absolute values of $0.124 \%$ and $0.113 \%$ for the exponential and linear broken-line models, respectively). Therefore it was decided to use the estimated SID-LYS requirements based on the quadratic broken-line model as the basis for deriving SID-LYS recommendations for BWG and FCR. In Appendix B the estimated quadratic broken-line model parameters for each titration trial is given.

For a number of titration trials ( 4 titration trials for FCR and 5 titration trials for BWG) it was not possible to estimate reliable or unique SID-LYS requirements using the quadratic brokenline procedure. Furthermore, there was only one study in which female and male chicken were mixed and it was observed that this was also the only study that resulted in estimated SID-LYS requirements for FCR and BWG that were outliers compared to the other observations. The results of this study with mixed sex therefore were not included in the further work of establishing relationships between estimated SID-LYS requirements for FCR/BWG and other factors such as age and sex of the broilers.

In Table 2 the dietary non-test SID-AA : estimated SID-LYS requirements ratios using the quadratic broken-line procedure for FCR and BWG are given together with the recommended CVB apparent fecal digestible (AFD) ratios. Results in Table 2 show that on average the estimated SID-LYS requirement estimates could not have negatively be impacted with limiting non-test AA levels although in some trials some non-test AA levels could have had a negative impact on estimated SID-LYS levels as a comparison between 
recommended CVB ratios and minimal ratios for both FCR and BWG observed in this study show. However, a visual inspection of graphs in which the various ratios were plotted against estimated SID-LYS requirements did not show deviating SID-LYS requirement estimates at suboptimal low ratios.

Table 2. Dietary non-test SID-AA : estimated SID-LYS requirement ratios using the quadratic broken-line procedure for FCR and BWG and compared to the recommended (Rec.) CVB apparent faecal digestible (AFD) ratios.

\begin{tabular}{|c|c|c|c|c|c|c|c|c|c|}
\hline \multirow[b]{2}{*}{ Ratio } & \multirow{2}{*}{$\begin{array}{l}\text { Rec. } \\
\text { CVB } \\
\text { AFD } \\
\text { ratio }\end{array}$} & \multicolumn{4}{|c|}{ FCR } & \multicolumn{4}{|c|}{ BWG } \\
\hline & & Mean & $\begin{array}{l}\text { Std. } \\
\text { Dev. }\end{array}$ & Min & Max & Mean & $\begin{array}{l}\text { Std. } \\
\text { Dev. }\end{array}$ & Min & Max \\
\hline MET: LYS & 38 & 53 & 10.3 & 37 & 79 & 55 & 10.8 & 36 & 81 \\
\hline M+C:LYS & 73 & 76 & 11.8 & 52 & 106 & 79 & 11.4 & 56 & 109 \\
\hline THR:LYS & 65 & 67 & 6.6 & 57 & 84 & 70 & 7.7 & 60 & 88 \\
\hline TRP:YS & 16 & 17 & 2.2 & 12 & 22 & 18 & 2.1 & 13 & 23 \\
\hline ILE:LYS & 66 & 72 & 6.4 & 57 & 84 & 75 & 6.3 & 59 & 88 \\
\hline ARG:LYS & 105 & 112 & 9.8 & 93 & 132 & 117 & 9.3 & 100 & 134 \\
\hline VAL:LYS & 80 & 82 & 6.6 & 66 & 96 & 86 & 7.0 & 71 & 101 \\
\hline
\end{tabular}

\subsection{Estimation of SID-LYS requirements for maximum BWG}

It appeared that mean age was the factor that could explain most variation in estimated SIDLYS requirements for maximum BWG (Table 3). Factors such as sex, protein level and ME level were not significant when added as covariables next to mean age and mean age squared.

Table 3. Regression formula to estimate the SID-LYS requirement for maximum BWG (\% in diet).

\begin{tabular}{|l|l|l|l|l|}
\hline F. & Intercept & Mean age $(d)$ & $(\text { Mean age }(d))^{\wedge} 2$ & $R^{2}$ \\
\hline 1 & $1.050 \pm 0.0196$ & & & 0.000 \\
\hline 2 & $1.153 \pm 0.0286$ & $-0.00542 \pm 0.001284$ & & 0.324 \\
\hline 3 & $1.261 \pm 0.0469$ & $-0.01919 \pm 0.005086$ & $0.000316 \pm 0.000115$ & 0.438 \\
\hline
\end{tabular}

Although F.3 explains more variation in SID-LYS requirement for maximum BWG compared to F.2 (Table 3), the result is that after an initial decrease in SID-LYS requirement at increasing age the predicted SID-LYS requirement increases again as age increases. This is not logical from a physiological point of view and therefore it was chosen to fit a natural logarithmic relationship. This resulted in the formula presented in F.4:

F.4: SID-LYS req. for max BWG $(\%$ in diet $)=1.280 \pm 0.03029-0.1394 \pm 0.04184 \times \log ($ mean age $(d)) ; R^{2}=0.395$.

Although dietary ME was not significant in explaining variation in estimated SID-LYS for BWG when it was added as a covariable to the model next to the factors mean age and mean age squared, when expressing the estimated SID-LYS requirements for maximum BWG relative to dietary ME content it resulted in a formula (F. 5) that explained substantial more variation compared to formula F.4:

F.5: SID-LYS req. for max BWG ((\% est. SID LYS in diet for max. BWG : MEpo (Kcal))*1000) $=0.462 \pm 0.01971-0.0419 \pm 0.00696 \times \log ($ mean age $(d)) ; R^{2}=0.477$. 
Also it is from a physiological point of view logical to take the dietary ME content into consideration as an increase in dietary ME content enables a higher growth and protein retention per unit of feed consumed and thereby also necessitates a higher SID-LYS requirement per unit of feed consumed. In Figure 1 the relationship between mean age (days) and the SID-LYS req. for max BWG ((\% SID LYS in diet : MEpo (Kcal/kg))*1000) ratio is shown.

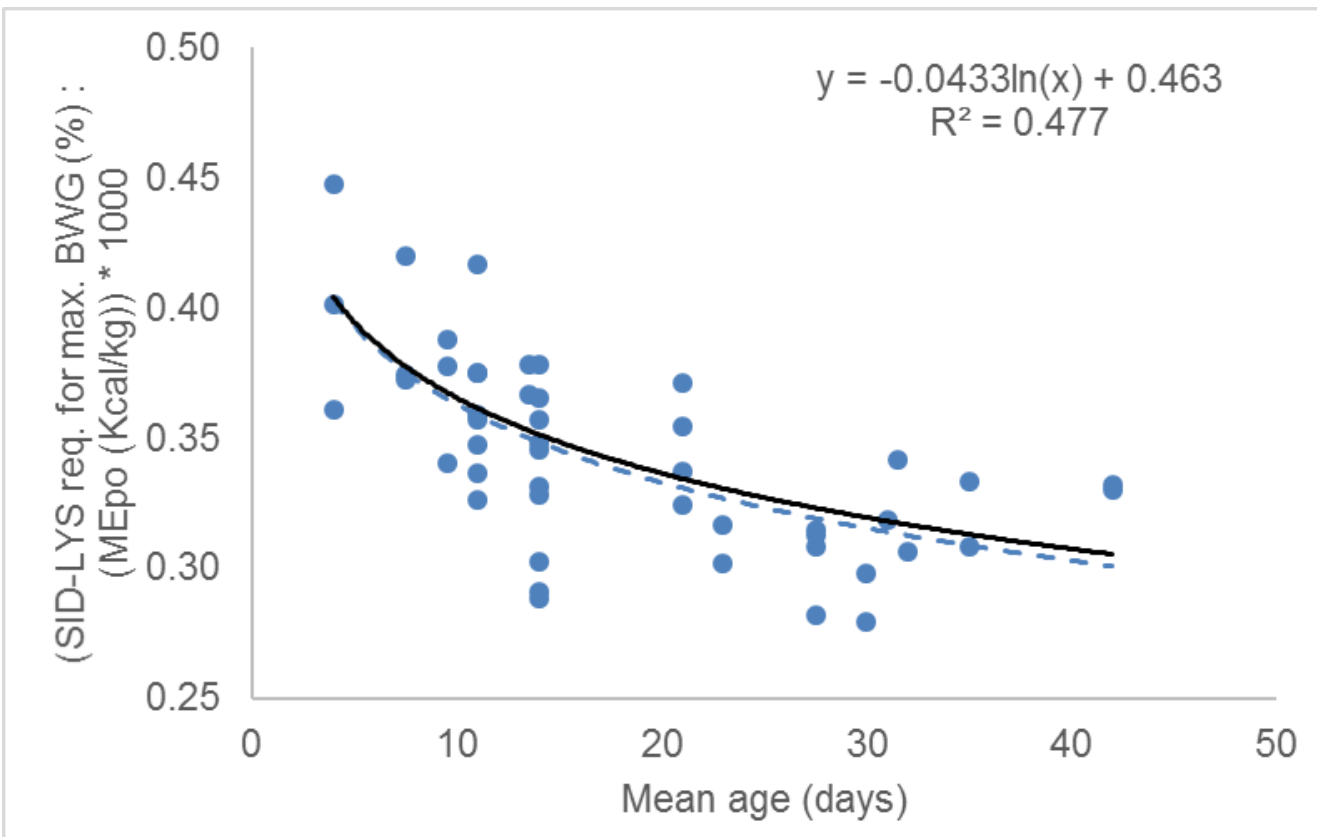

Figure 1. Relationship between mean age and the SID-LYS req. for max BWG ((\% SID LYS in diet : MEpo (Kcal/kg))*1000). The solid line represents formula F.5 and takes into account a study effect whereas the dashed line represents the formula shown in the Figure and does not take into account a study effect.

It is also possible to regress the model estimated SID-LYS requirements for maximum BWG against the model estimated plateau values of FCR and this type of regression formula might be useful in order to determine SID-LYS requirements for maximum BWG for deviating conditions such as birds with extremely low or high FCR. This resulted in the following regression formula for BWG:

F.6. SID-LYS req. for max BWG ((\% est. SID LYS in diet for max. BWG : MEpo $\left.(\mathrm{Kcal} / \mathrm{kg}))^{\star} 1000\right)=0.560 \pm 0.0316-0.141 \pm 0.0206 \times \mathrm{FCR}(\mathrm{g}$ feed $: \mathrm{g} \mathrm{BWG}) ; \mathrm{R}^{2}=0.564$

\subsection{Estimation of SID-LYS requirements for minimum FCR}

In contrast to the estimation of the SID-LYS req. for maximum BWG less variation in SIDLYS req. for minimum FCR could be explained. It appeared that mean age was the factor that could explain most variation in SID-LYS requirement for minimum FCR (Table 4). Contrary to BWG there was no significant quadratic effect of mean age on SID-LYS req. for minimum FCR. Factors such as sex, protein level and ME level were not significant when added as covariables next to mean age and mean age squared. 
Table 4. Regression formula to estimate the SID-LYS requirement for minimal FCR.

\begin{tabular}{|l|l|l|l|}
\hline F. & Intercept & Mean age $(\mathrm{d})$ & $\mathrm{R}^{2}$ \\
\hline 7 & $1.083 \pm 0.0211$ & & 0.000 \\
\hline 8 & $1.167 \pm 0.0338$ & $-0.00414 \pm 0.001461$ & 0.203 \\
\hline
\end{tabular}

Although dietary energy was not significant in explaining variation in estimated SID-LYS for BWG when it was added as a covariable to the model next to the factor mean age, when expressing the estimated SID-LYS requirements for maximum BWG relative to dietary ME content it resulted in a formula (F.9) that explained more variation compared to formula F.8:

F.9: SID-LYS req. for min. FCR ((\% est. SID LYS in diet for min. FCR : MEpo $($ Kcal $\left.))^{\star} 1000\right)=$ $0.467 \pm 0.0257-0.0378 \pm 0.00907 \times \log ($ mean age $(d)) ; R^{2}=0.287$

It is also possible to regress the model estimated SID-LYS requirements for minimum FCR against the model estimated plateau value of FCR and this type of regression formula might be useful for extreme conditions such as birds with extremely low or high FCR. This resulted in the following regression formula for FCR:

F.10. SID-LYS req. for min. FCR ((\% est. SID LYS in diet for min. FCR : MEpo

$\left.(\mathrm{Kcal} / \mathrm{kg}))^{\star} 1000\right)=0.568 \pm 0.0349-0.135 \pm 0.0225 \times \mathrm{FCR}(\mathrm{g}$ feed $: \mathrm{g} \mathrm{BWG}) ; \mathrm{R}^{2}=0.432$. 


\section{Conclusions}

Based on the results of this study it is concluded that formula F.5 is most suited to predict SID-LYS recommendations for maximum BWG and formula F.9 to predict SID-LYS recommendations for minimum FCR. In Table 5 the SID-LYS requirements for BWG and FCR at the various growing periods are presented. These MEpo values are average MEpo values based on 2017 data from three Dutch compound feed companies.

Table 5. Estimated requirement levels for SID-LYS $(\mathrm{g} / \mathrm{kg}$ ) for BWG and FCR based on formula F.5 for BWG and F.9 for FCR.

\begin{tabular}{|l|l|l|l|l|}
\hline Growing period & MEpo (Kcal/kg) & $\begin{array}{l}\text { MEbr } \\
(\text { Kcal/kg) }\end{array}$ & SID-LYS (BWG) & SID-LYS (FCR) \\
\hline Week 1 & 2920 & 2840 & 12.0 & 12.3 \\
\hline Week 2 & 3020 & 2920 & 11.0 & 11.4 \\
\hline Weeks 3-4 & 3040 & 2940 & 10.2 & 10.7 \\
\hline Weeks $>4$ & 3100 & 3000 & 9.7 & 10.3 \\
\hline
\end{tabular}

*MEpo values are average MEpo values based on 2017 data from three Dutch compound feed companies.

*MEbr was derived from MEpo by assuming a diet containing $40 \%$ wheat (with a STAam content of $58 \%$ ), $20 \%$ maize, $30 \%$ soybean meal for all growing periods and inclusion of pure fat of, 2, 5, 5, and 5 percent for, respectively, the growing periods week 1 , week 2 , week $3-4$ and week $>4$. 


\section{List of studies included in the meta-analysis}

Abdel-Maksoud, A., F. Yan, S. Cerrate, C. Coto, Z. Wang, and P. W. Waldroup. 2010. Effect of dietary crude protein, lysine level and amino acid balance on performance of broilers 0 to 18 days of age. International Journal of Poultry Science 9:21-27.

Aftab, U., M. Ashraf, A. S. Mumtaz, and Z. Jiang. 2007. Lysine requirement of broiler chickens fed low-density diets under tropical conditions. Asian-Australasian Journal of Animal Sciences 20:939-943.

Barboza, W. A., H. S. Rostagno, L. F. T. Albino, and P. B. Rodrigues. 2000. Níveis de lisina para frangos de corte de 1 a 21 e 15 a 40 dias de idade. Revista Brasileira de Zootecnia 29:1082-1090.

Berri, C., J. Besnard, and C. Relandeau. 2008. Increasing Dietary Lysine Increases Final pH and Decreases Drip Loss of Broiler Breast Meat. Poultry Science 87:480-484.

Borges, A. F., R. F. M. De Oliveira, J. L. Donzele, U. A. D. Orlando, R. A. Ferreira, and E. P. Saraiva. 2002. Lysine requirement of male broilers from 22 to 42 days of age kept under hot environment $\left(26^{\circ} \mathrm{C}\right)$. Revista Brasileira de Zootecnia 31:1993-2001.

Borges, A. F., R. F. M. De Oliveira, J. L. Donzele, L. F. T. Albino, U. A. D. Orlando, and R. A. Ferreira. 2002. Requirements of lysine for male broiler chicks under high temperature environment. Revista Brasileira de Zootecnia 31:394-401.

Corzo, A., W. A. Dozier lii, R. E. Loar li, M. T. Kidd, and P. B. Tillman. 2009. Assessing the threonine-to-lysine ratio of female broilers from 14 to 28 days of age. Journal of Applied Poultry Research 18:237-243. doi 10.3382/japr.2008-00107.

Dozier lii, W. A., A. Corzo, M. T. Kidd, P. B. Tillman, J. L. Purswell, and B. J. Kerr. 2009. Digestible lysine responses of male broilers from 14 to 28 days of age subjected to different environmental conditions. Journal of Applied Poultry Research 18:690-698. doi 10.3382/japr.2009-00016.

Dozier, W. A., A. Corzo, M. T. Kidd, P. B. Tillman, and S. L. Branton. 2009. Digestible lysine requirements of male and female broilers from fourteen to twenty-eight days of age. Poultry Science 88:1676-1682. doi 10.3382/ps.2008-00539.

Dozier lii, W. A., A. Corzo, M. T. Kidd, P. B. Tillman, J. P. McMurtry, and S. L. Branton. 2010. Digestible lysine requirements of male broilers from 28 to 42 days of age. Poultry Science 89:2173-2182. doi 10.3382/ps.2010-00710.

Dozier, W. A., and R. L. Payne. 2012. Digestible lysine requirements of female broilers from 1 to 15 days of age. Journal of Applied Poultry Research 21:348-357. doi 10.3382/japr.2011-00418.

Garcia, A. R., A. B. Batal, and D. H. Baker. 2006. Variations in the digestible lysine requirement of broiler chickens due to sex, performance parameters, rearing environment, and processing yield characteristics. Poultry Science 85:498-504.

Greenwood, M. W., K. R. Cramer, R. S. Beyer, P. M. Clark, and K. C. Behnke. 2005. Influence of feed form on estimated digestible lysine needs of male broilers from sixteen to thirty days of age. Journal of Applied Poultry Research 14:130-135.

Kidd, M. T., and B. I. Fancher. 2001. Lysine needs of starting chicks and subsequent effects during the growing period. Journal of Applied Poultry Research 10:385-393.

Mack, S., D. Bercovici, G. De Groote, B. Leclercq, M. Lippens, M. Pack, J. B. Schutte, and S. Van Cauwenberghe. 1999. Ideal amino acid profile and dietary lysine specification for broiler chickens of 20 to 40 days of age. British Poultry Science 40:257-265. doi $10.1080 / 00071669987683$.

Mahdavi, A., M. Shivazad, F. Alemi, M. Zaghari, H. Moravej, and B. Darabighane. 2012. Digestible lysine requirement of broilers based on practical diet. Italian Journal of Animal Science 11:e13. doi 10.4081/ijas.2012.e13.

Perazzo Costa, F. G., H. Santiago Rostagno, L. F. Teixeira Albino, P. C. Gomes, and R. Santana Toledo. 2001. Dietary Lysine Levels for Broilers Chickens from 1 to 21 and 22 to 40 Days of Age. Revista Brasileira de Zootecnia 30:1490-1497.

Zaboli, G. R., G. Jalilvand, A. A., Davarpanah, and M. Mehri. 2011. Estimation of standardized ileal digestible lysine requirement of starting broiler chicks fed 
soybean-and cottonseed meal-based diets. Journal of Animal and Veterinary Advances 10:1278-1282.

Zaghari, M., M. Shivazad, A. Kamyab, and A. Nikkhah. 2010. Digestible Lysine Requirement of Arian Male and Female Broiler Chicks During Six to Twenty-one Days of Age. Journal of Agricultural Science and Technology 4:111-117.

\section{References}

Blok and Dekker. 2017. Table 'Standardized ileal digestibility of amino acids in feedstuffs for poultry'. CVB Documentation report nr. 61.

Veldkamp , T., J. W. van Riel, R. A. Dekker, S. Khalaji, V. Khaksar, H. Hashemipour, M. M. van Krimpen, and M. C. Blok. 2016. Estimating requirement values for apparent faecal digestible and standardised ileal digestible lysine in broilers by a meta-analysis approach. 
Appendix A. Relationship between dietary SID-LYS supply and performance parameters FCR and BWG for the various titration trials including the estimated SID-LYS requirements based on the linear broken-line model, the quadratic broken- line model and the exponential model.

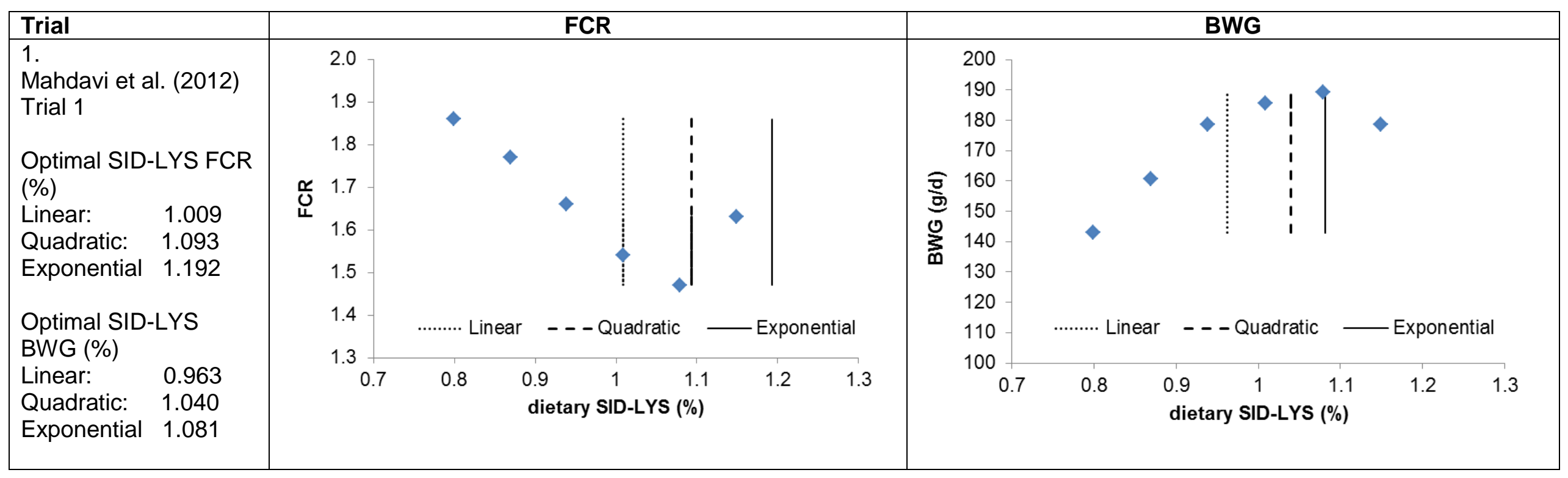




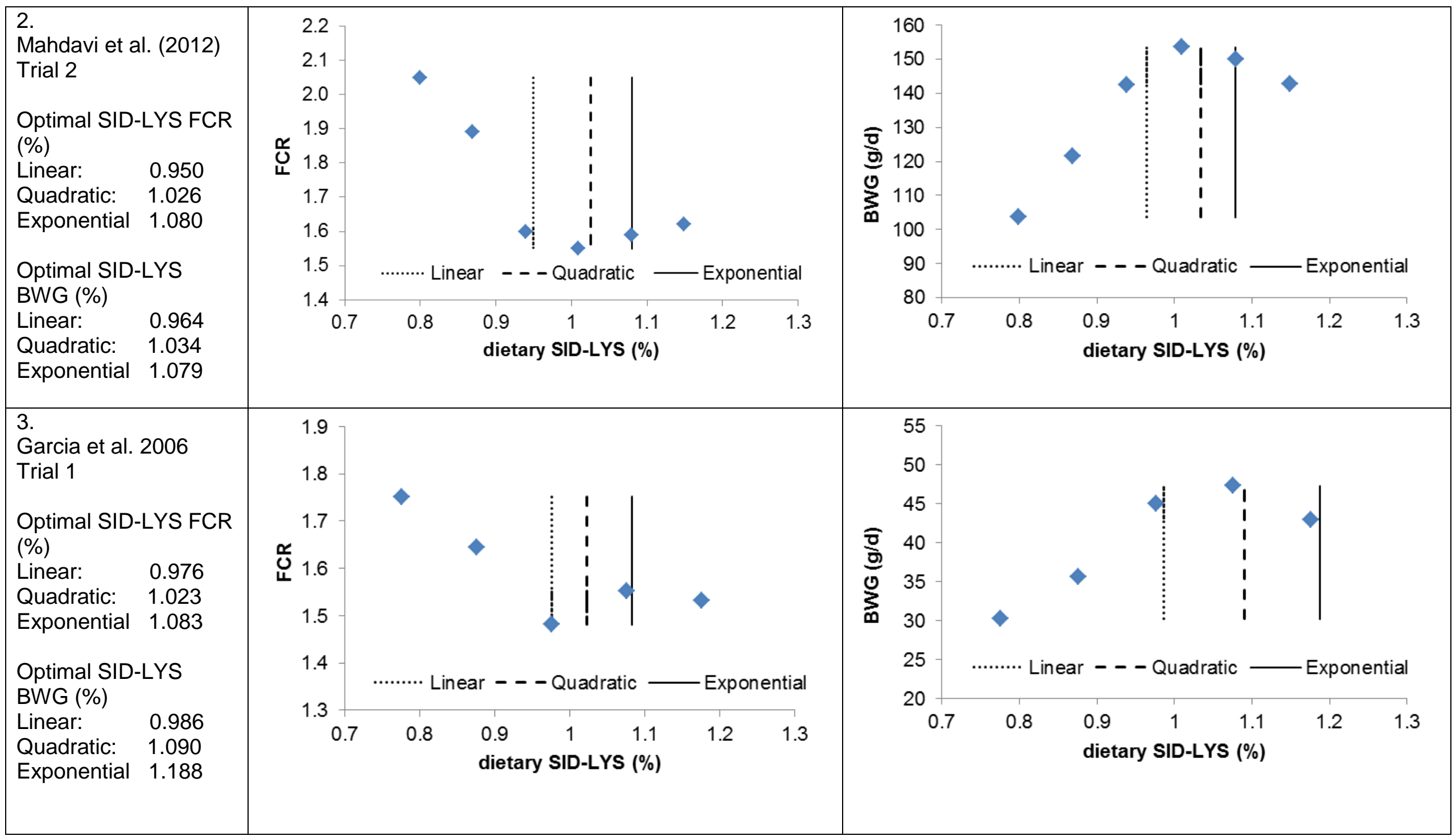




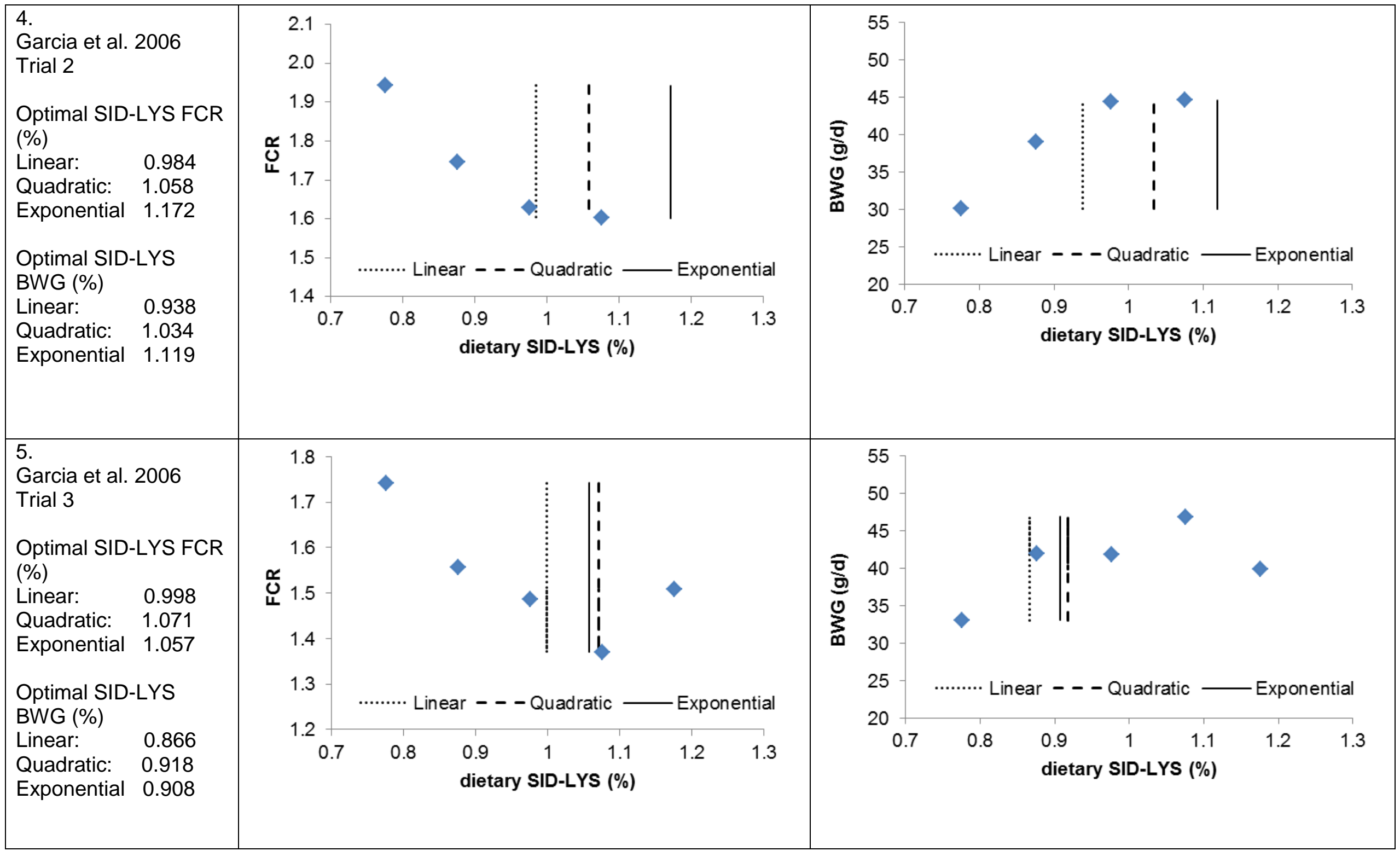




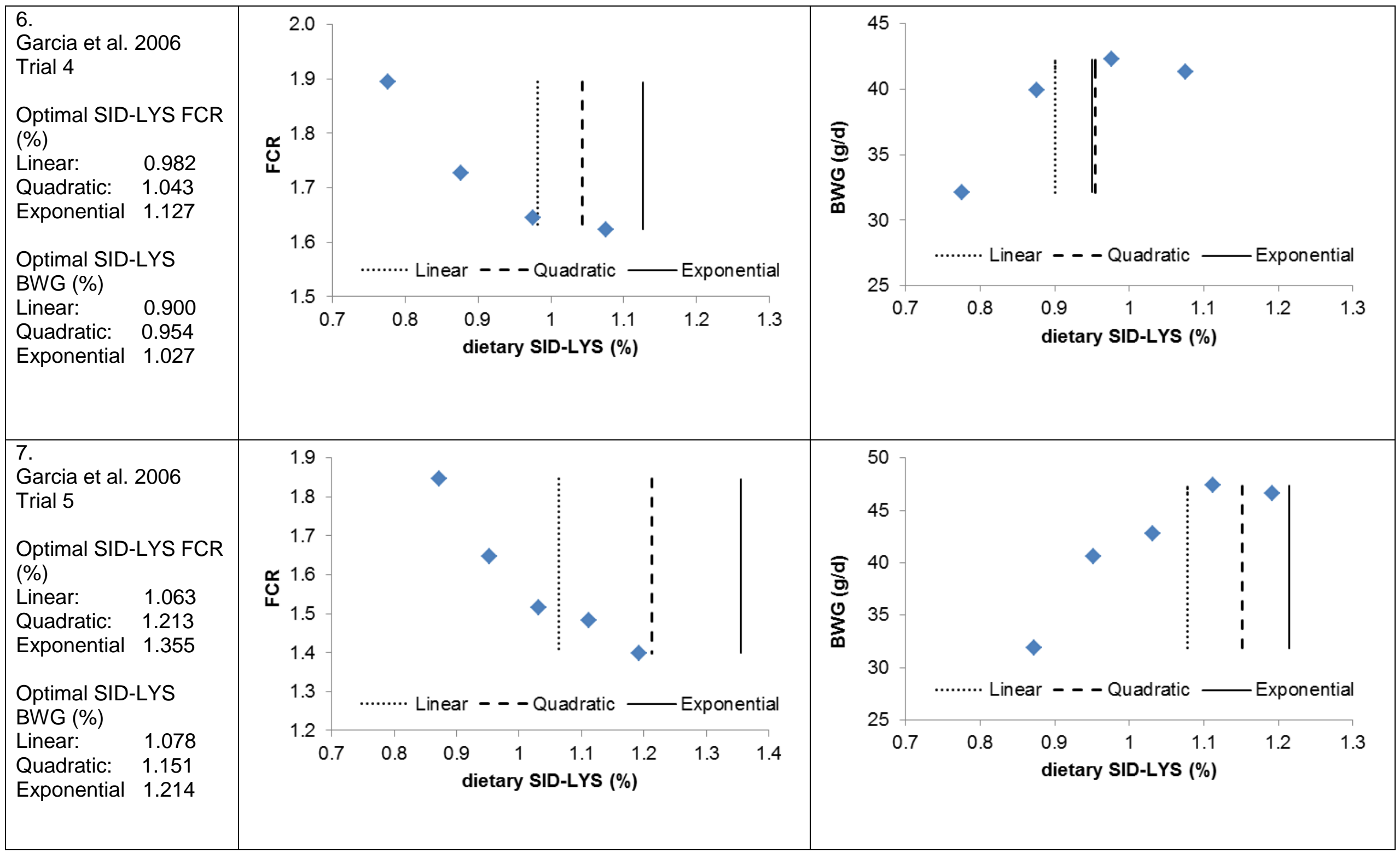




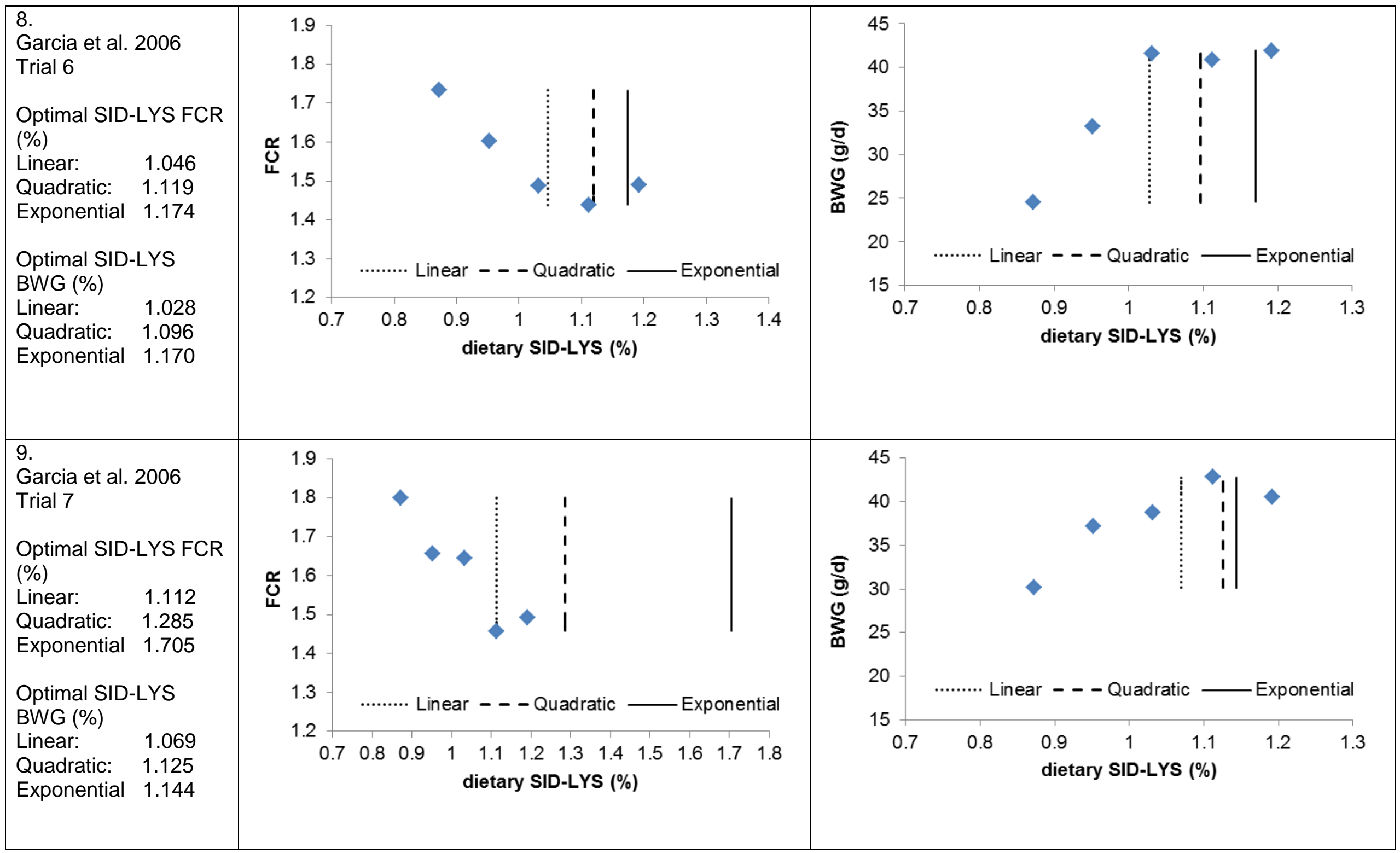




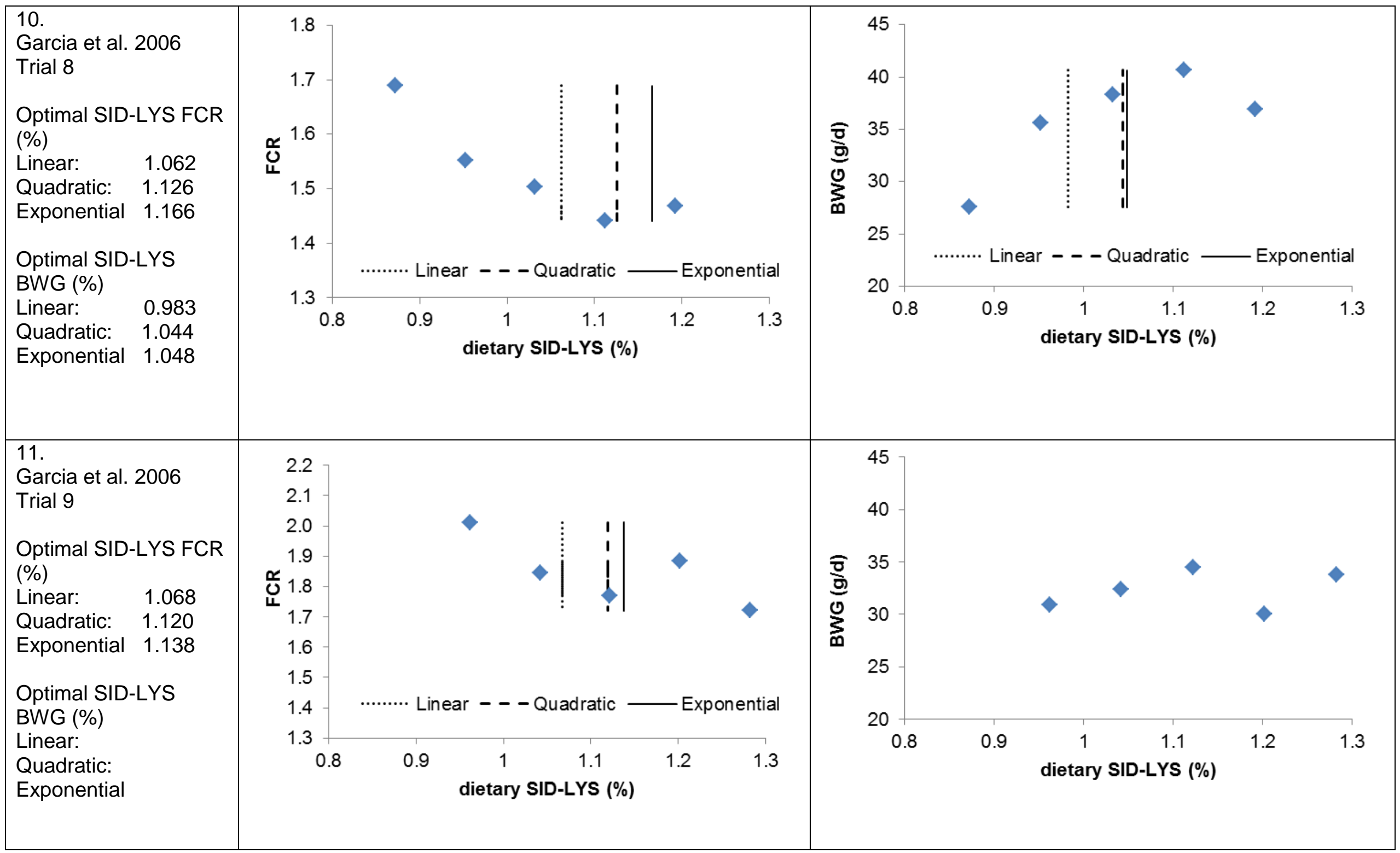




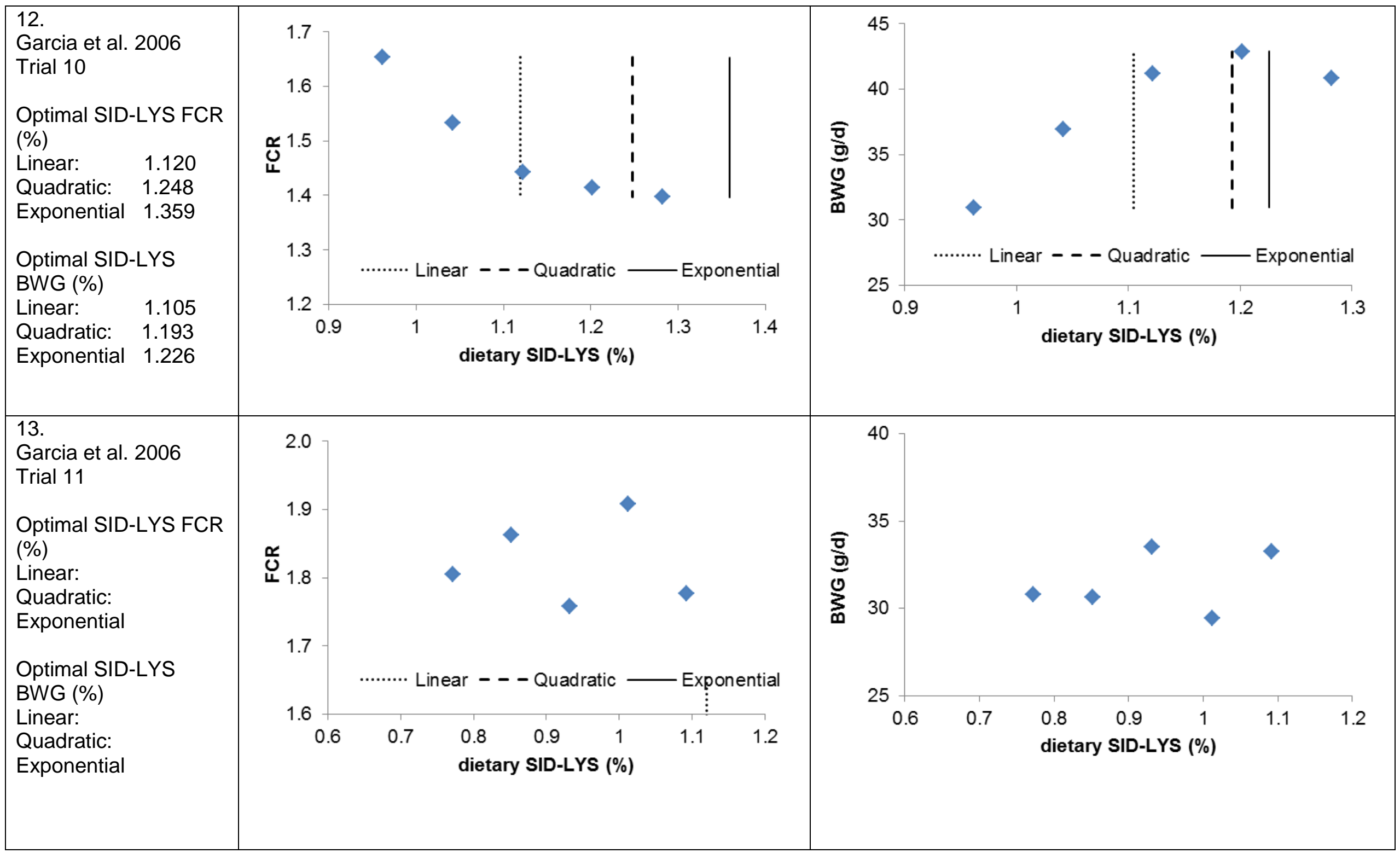




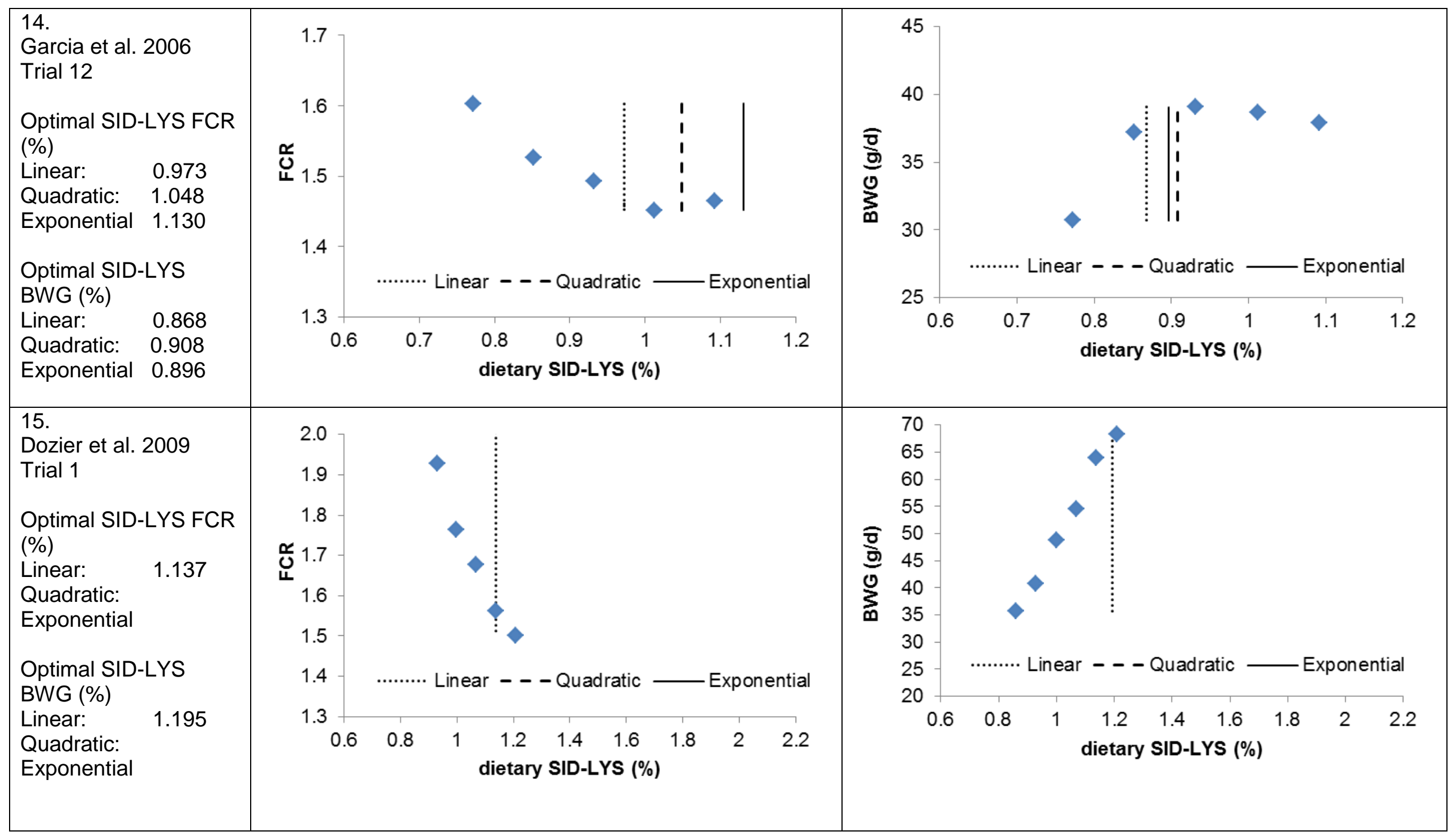




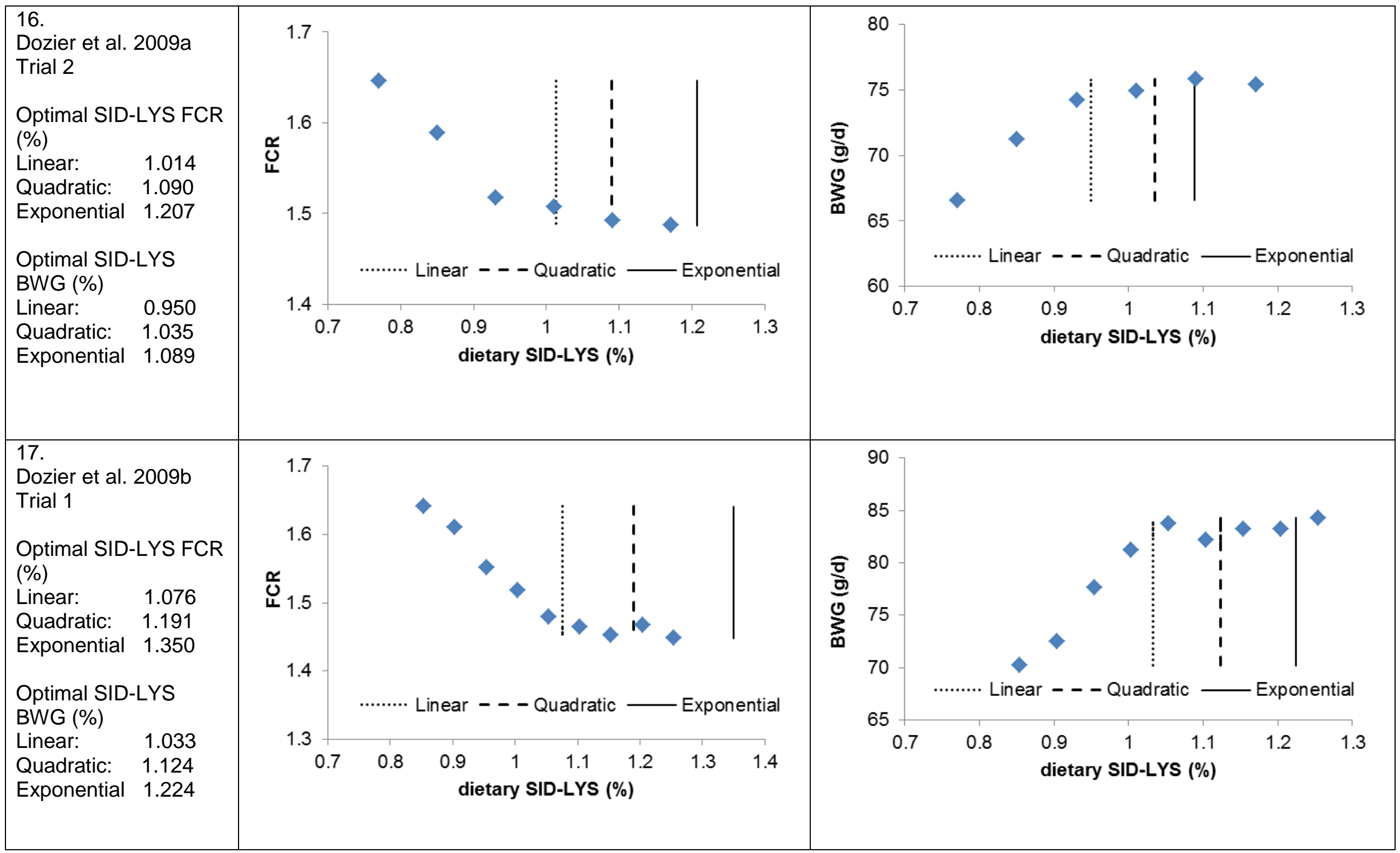




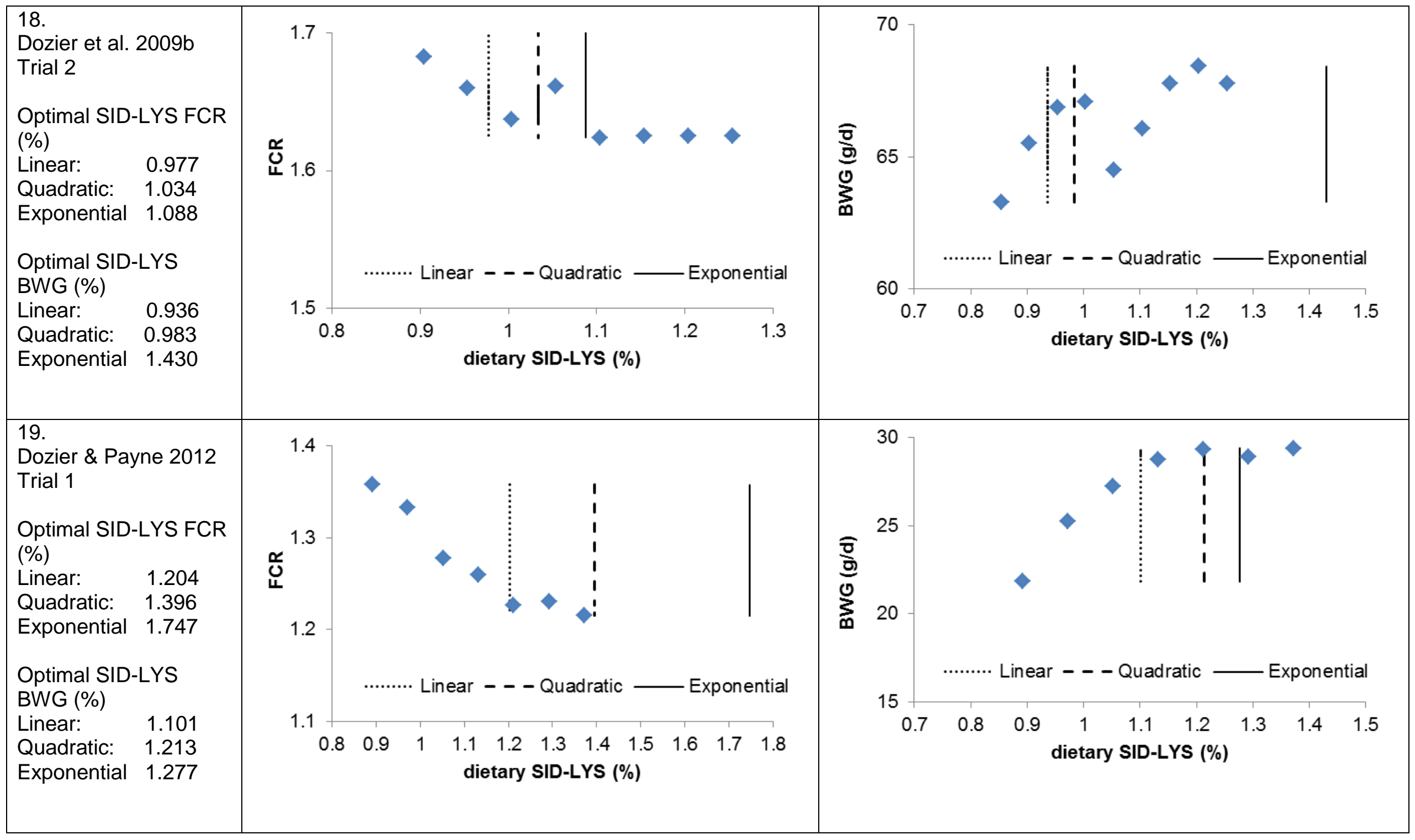




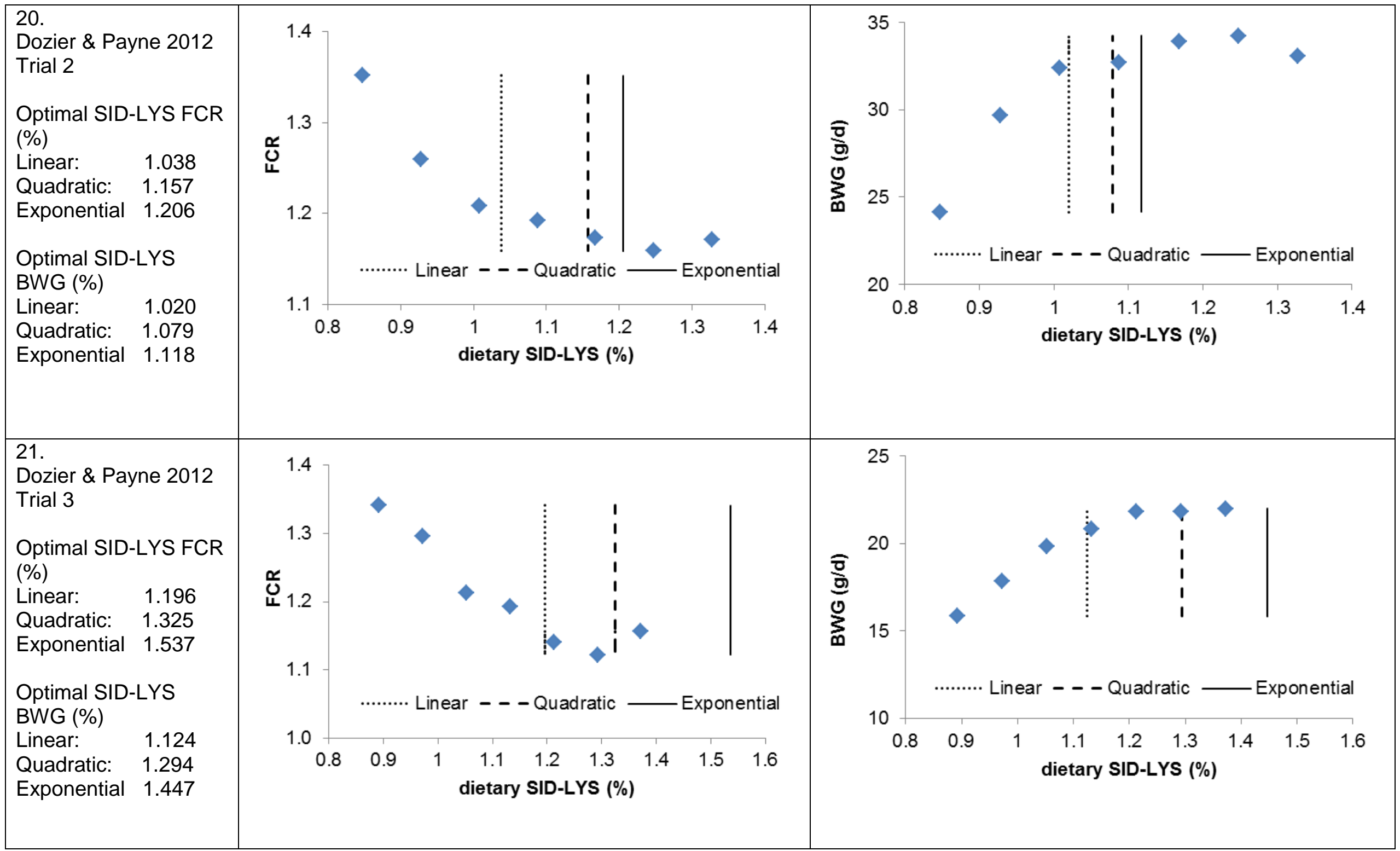




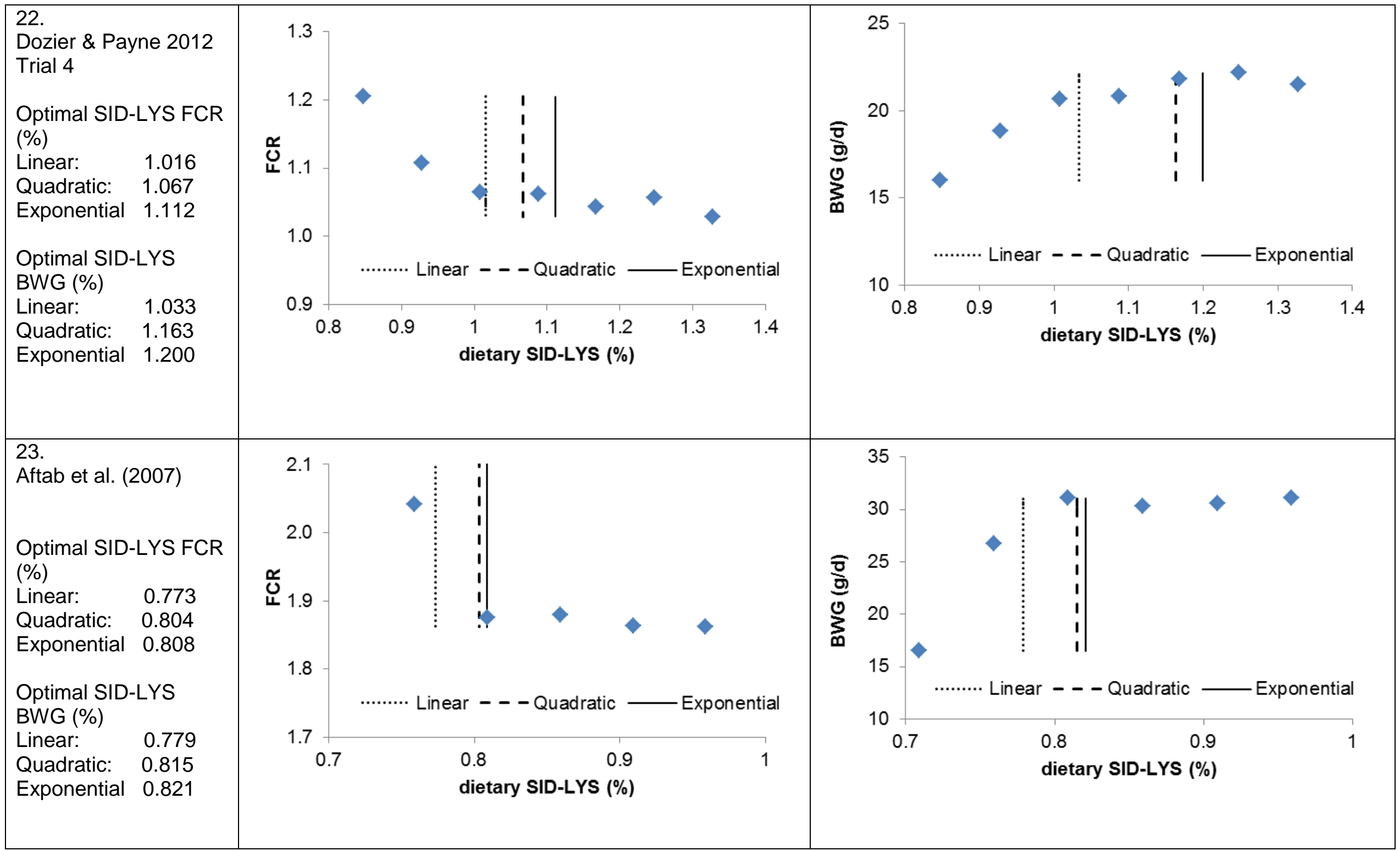




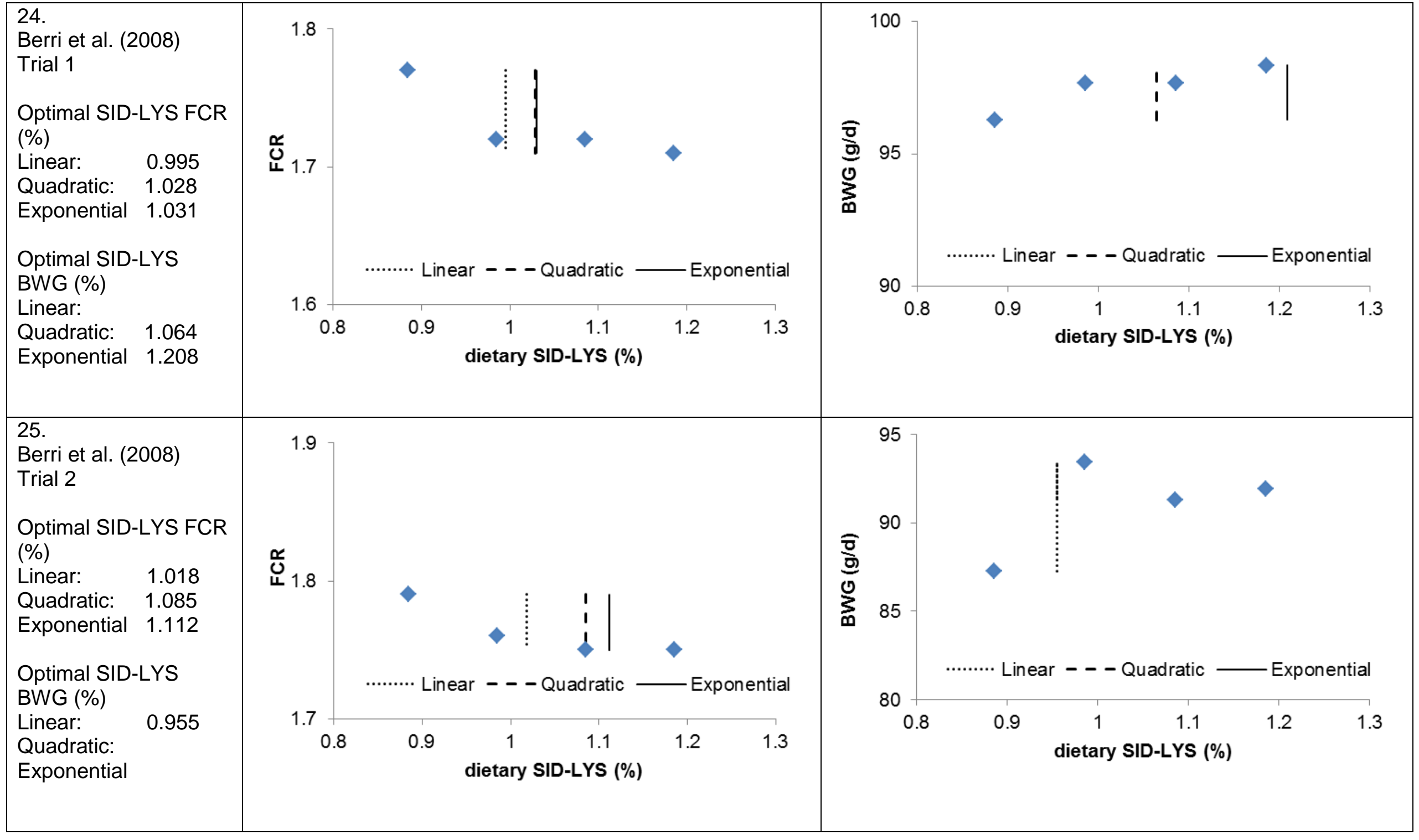




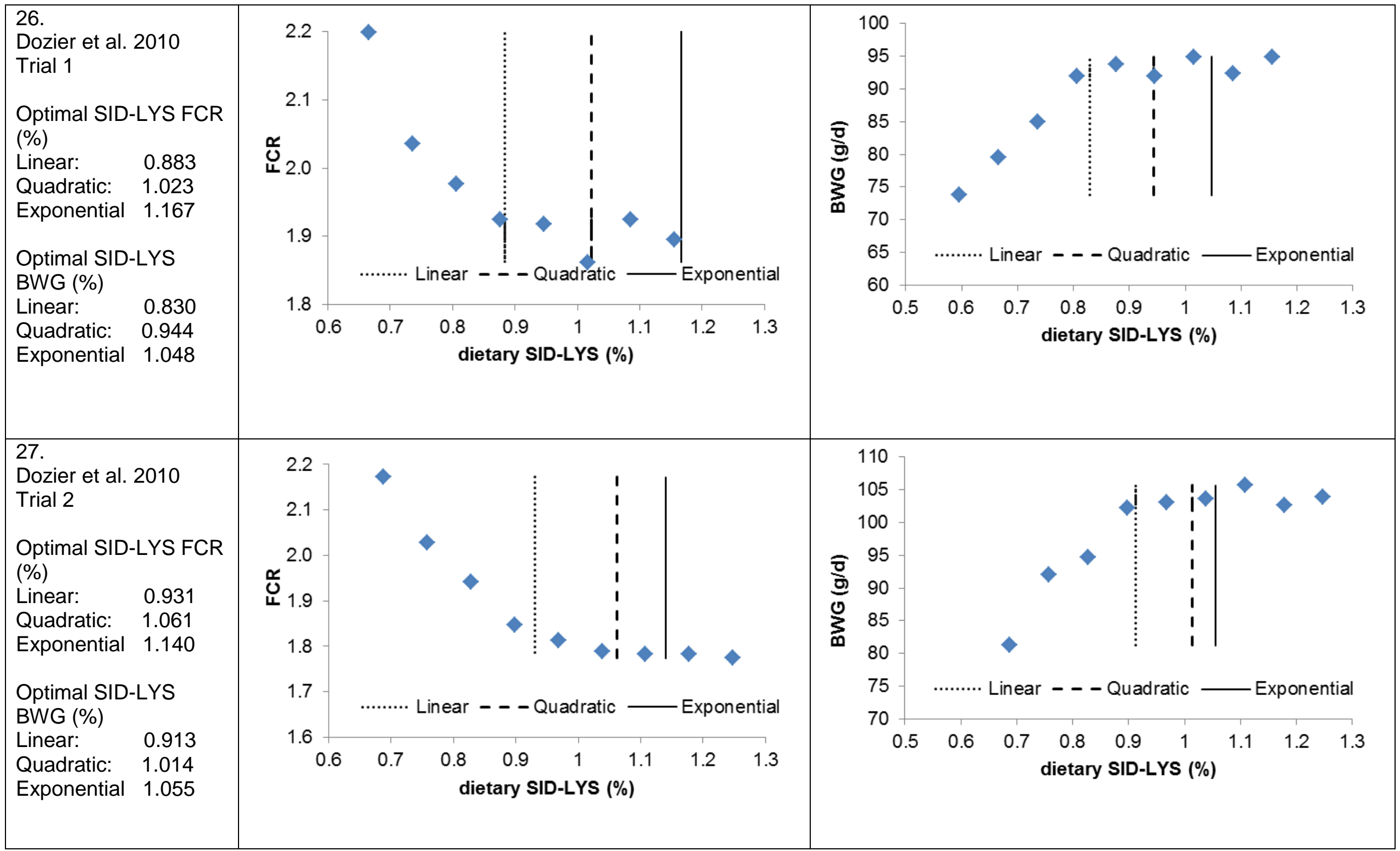




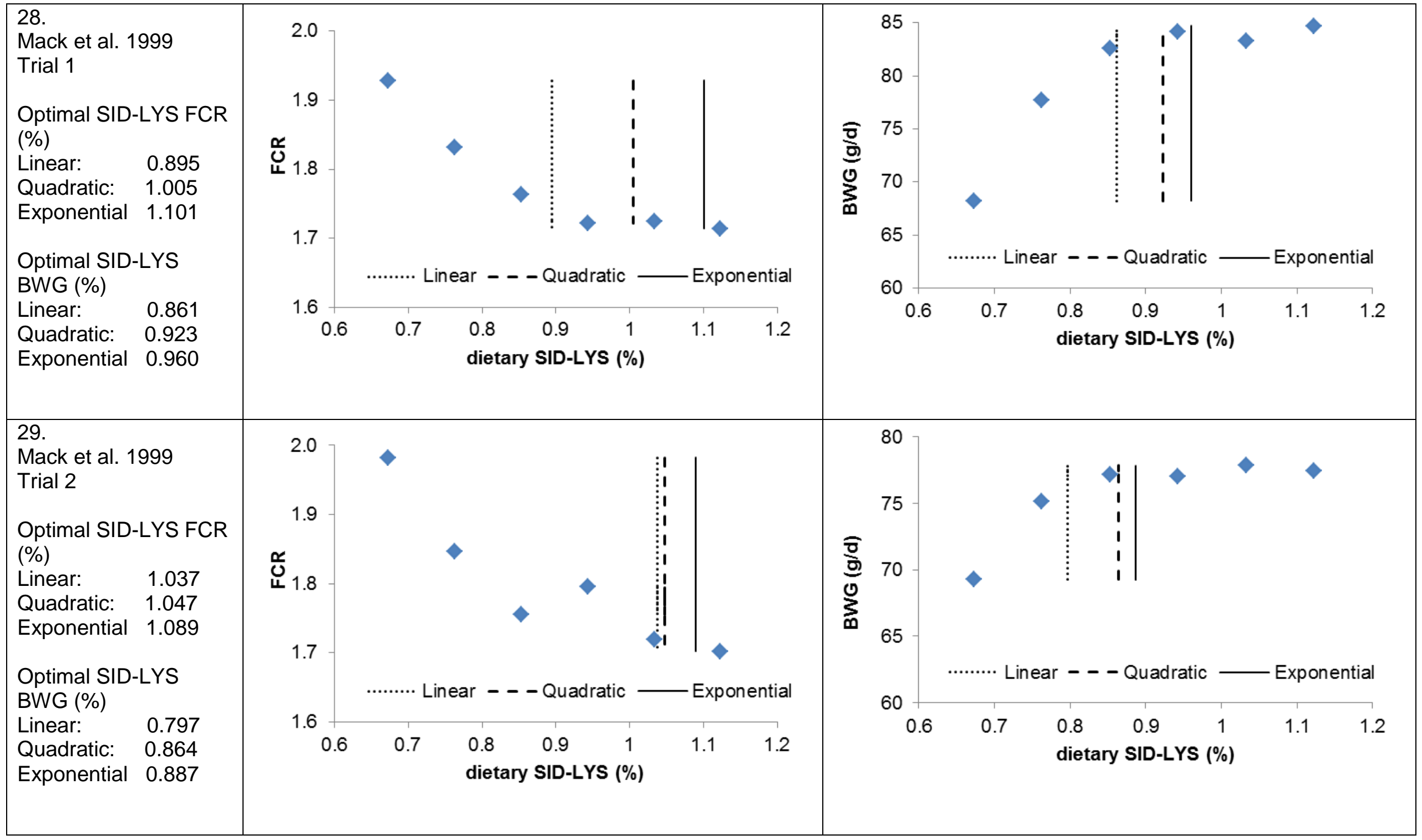




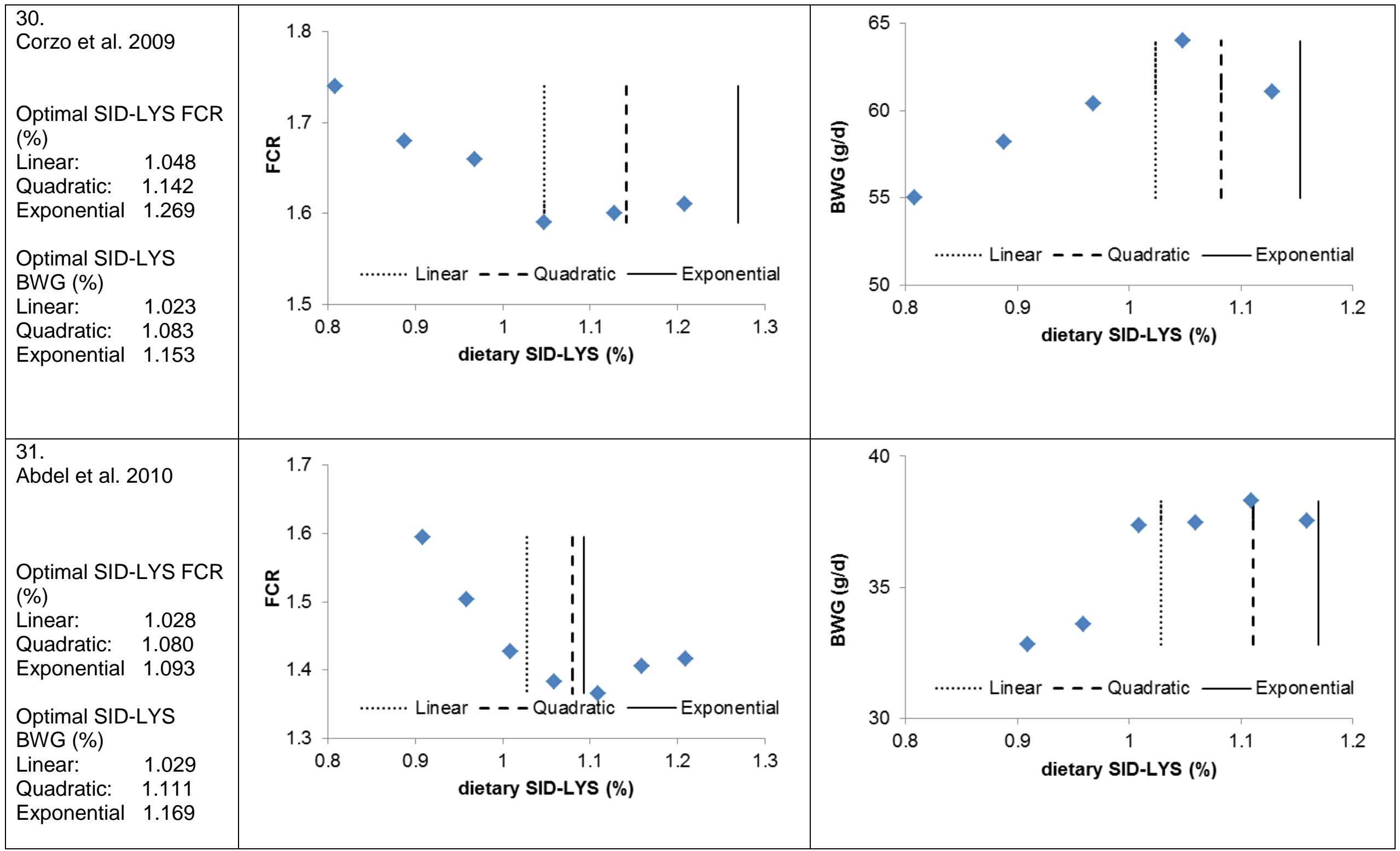




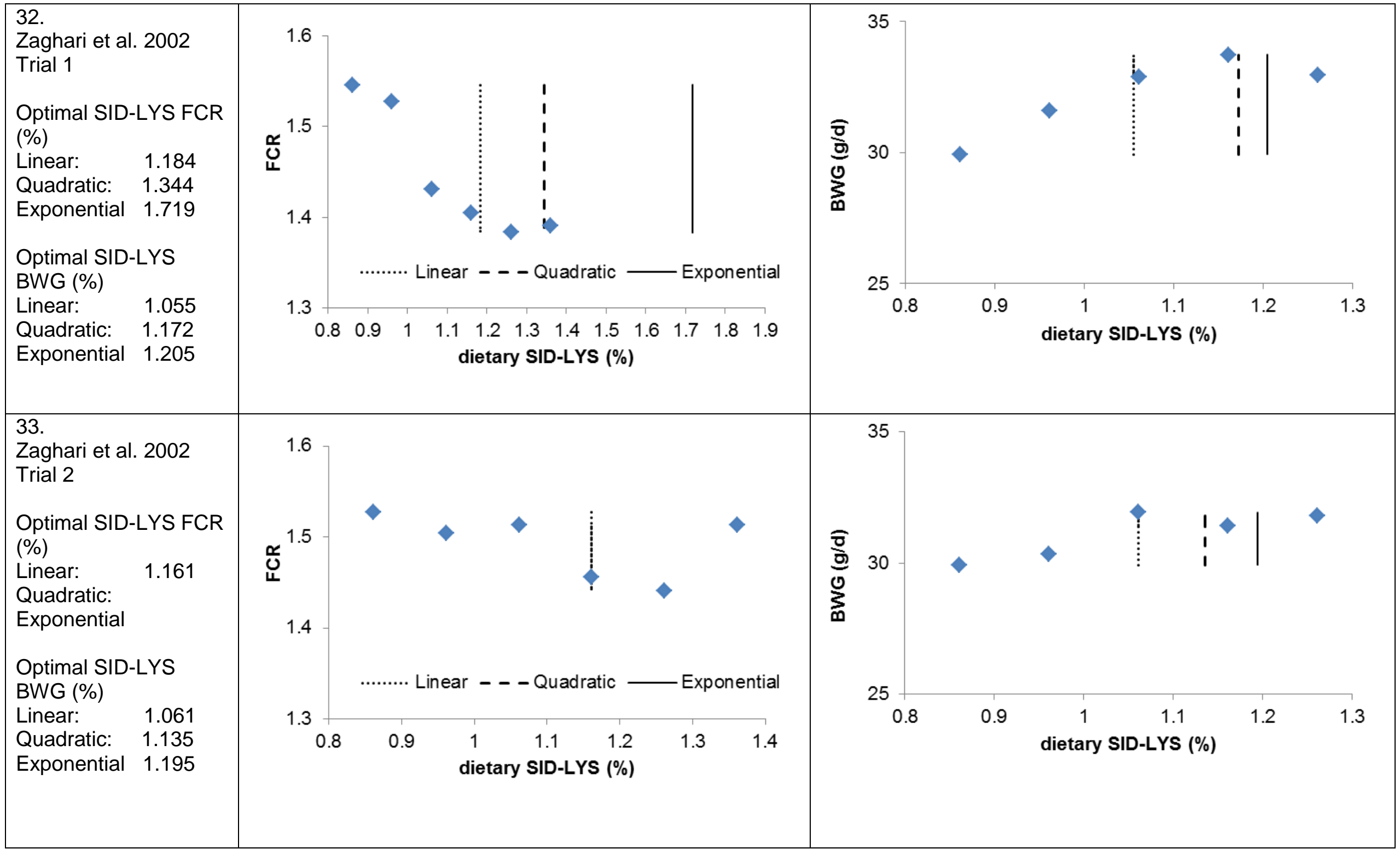




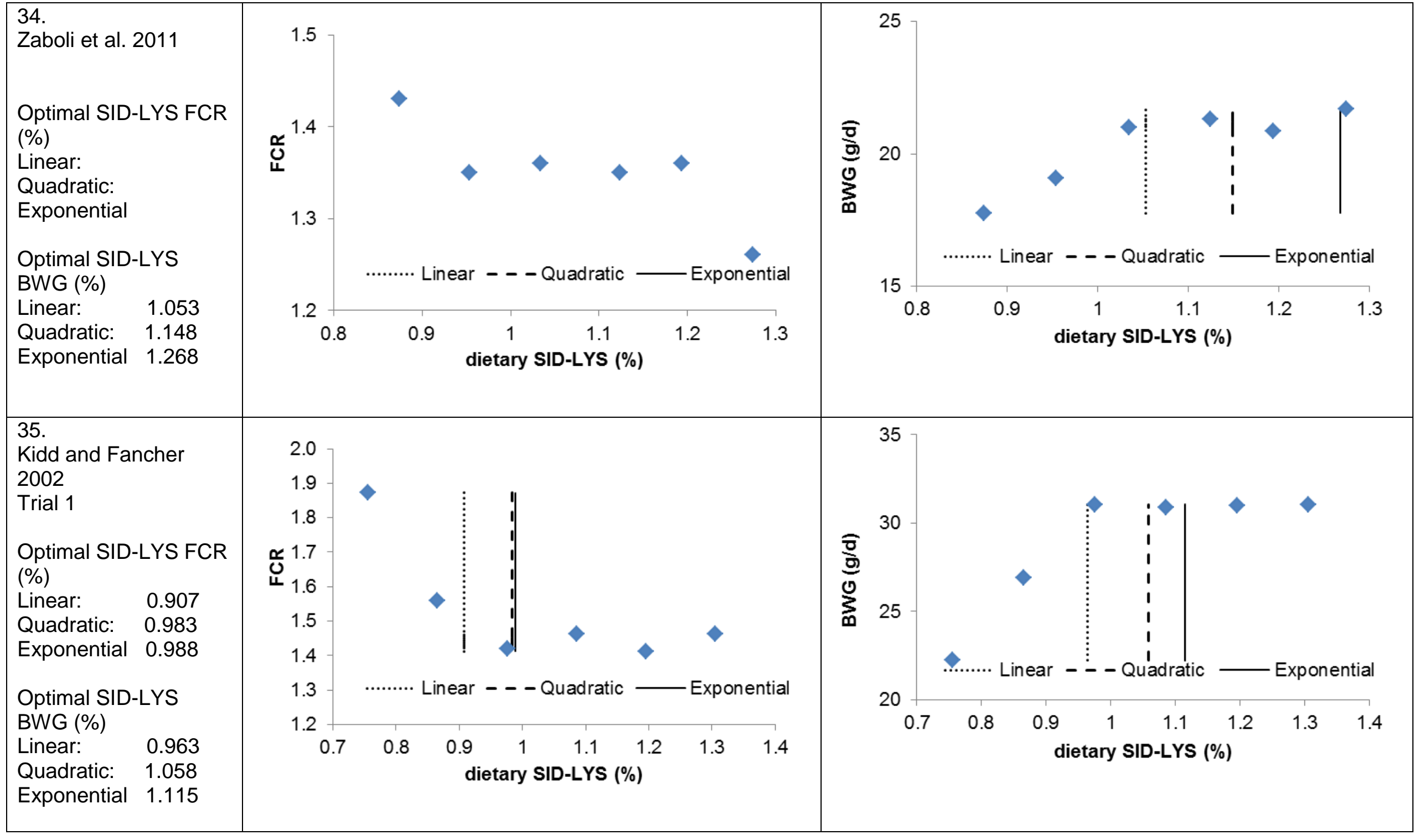




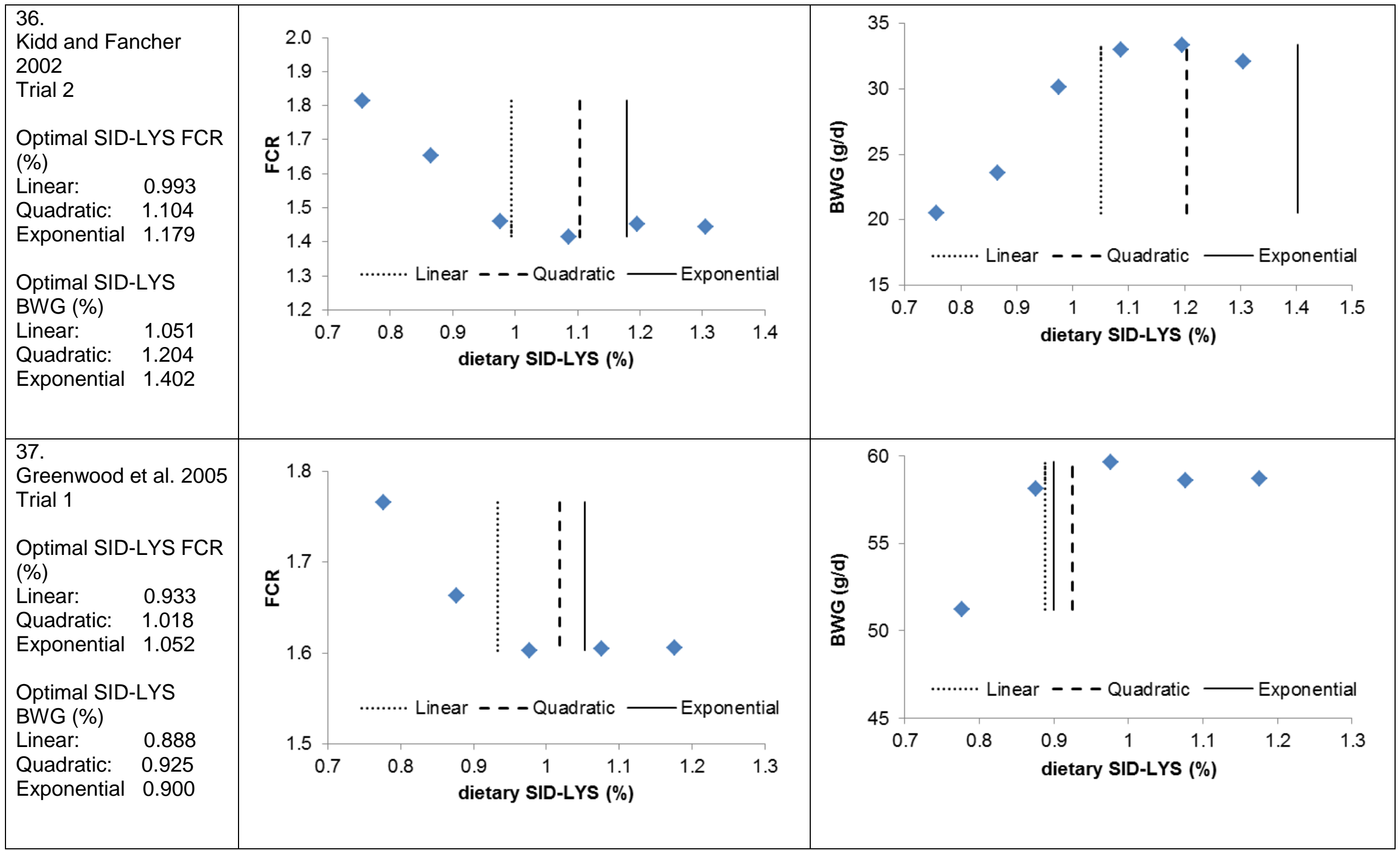




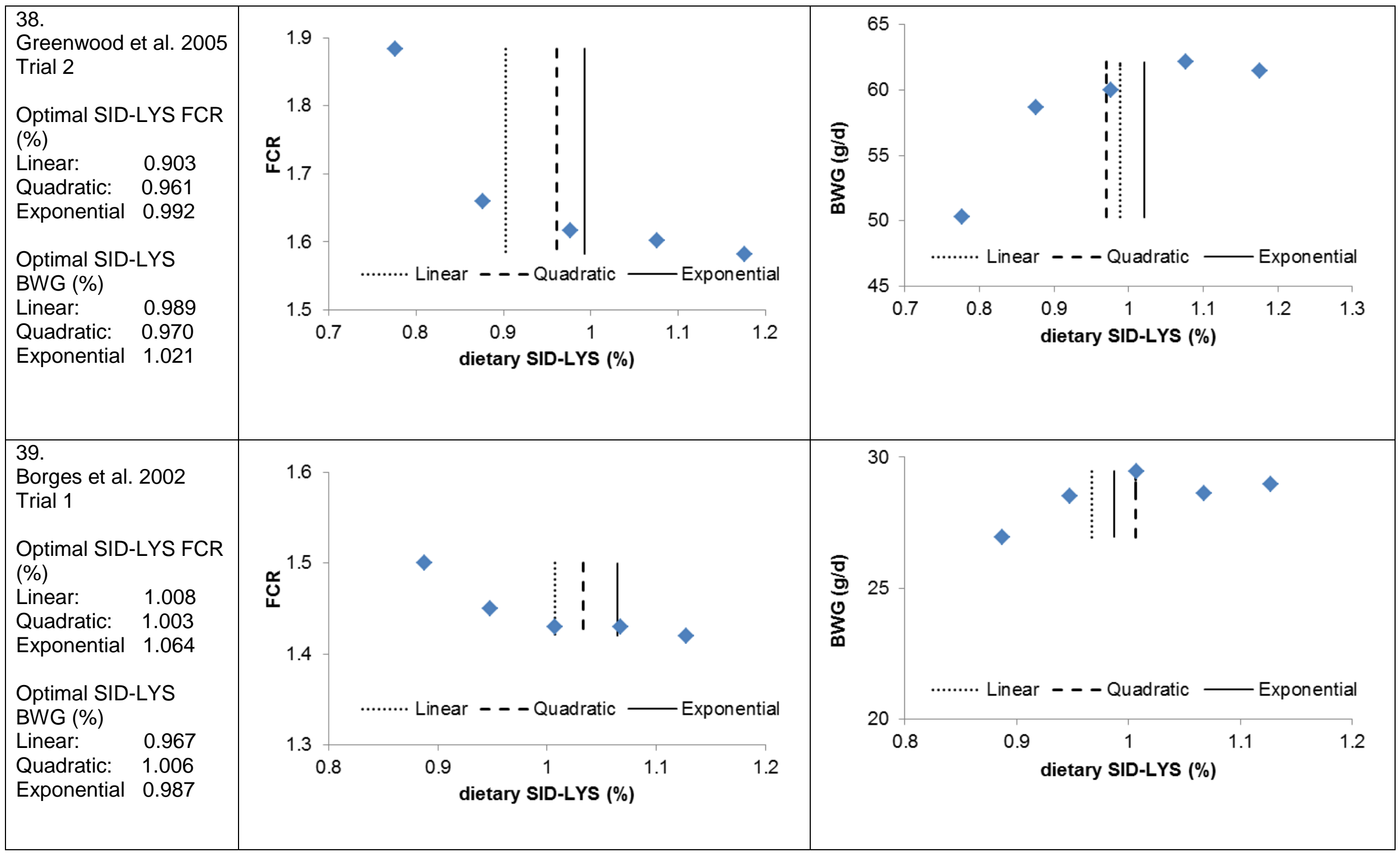




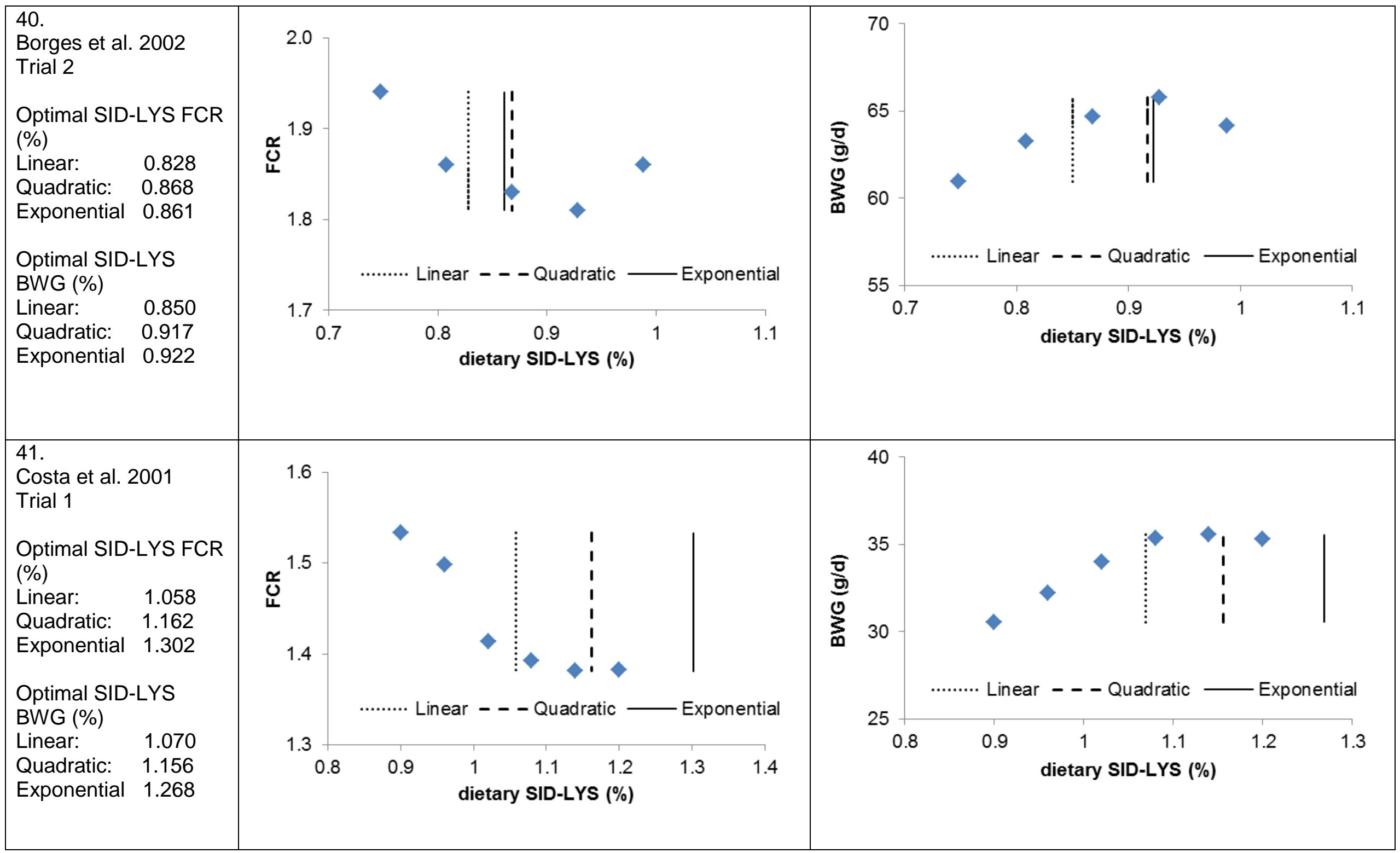




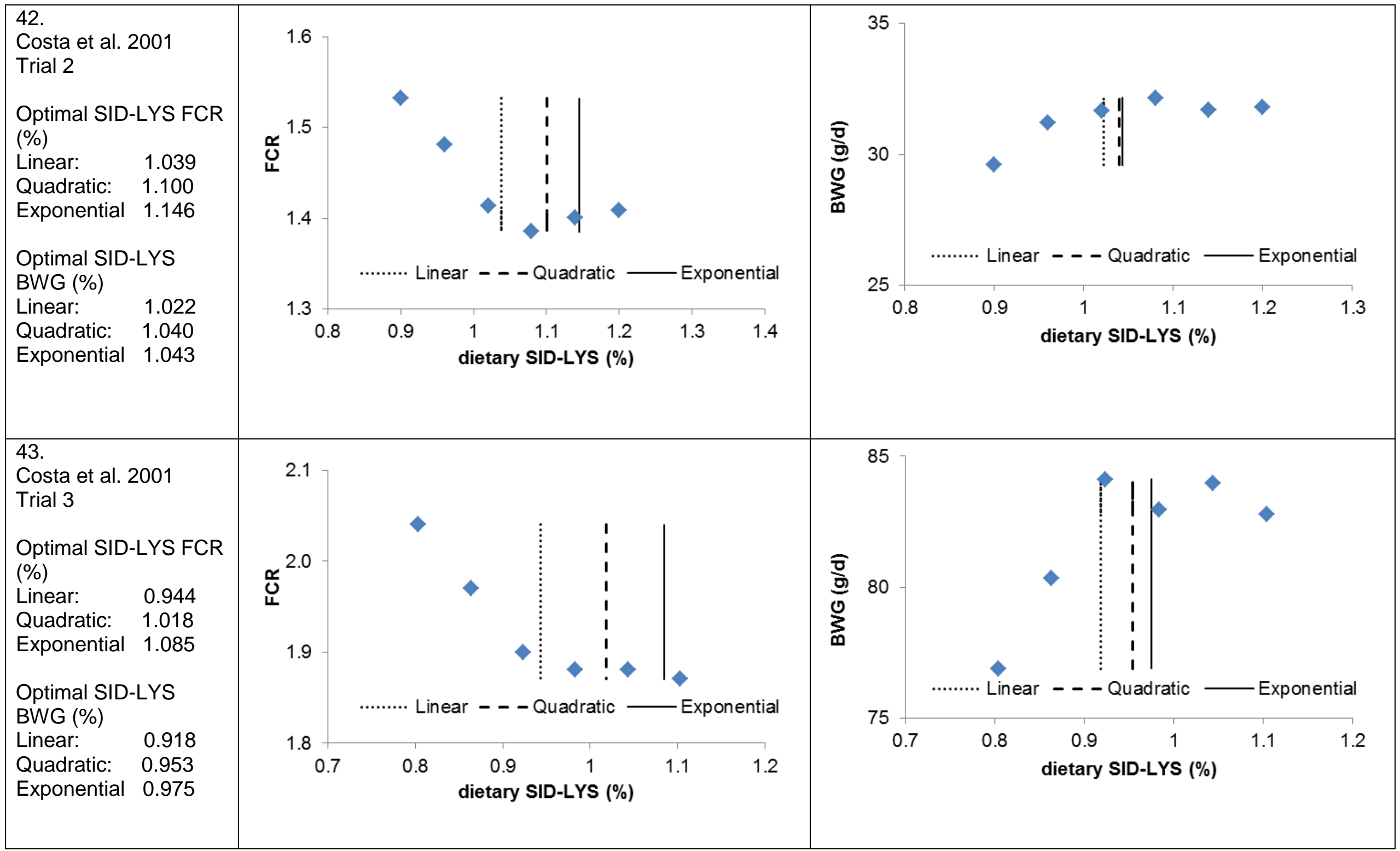




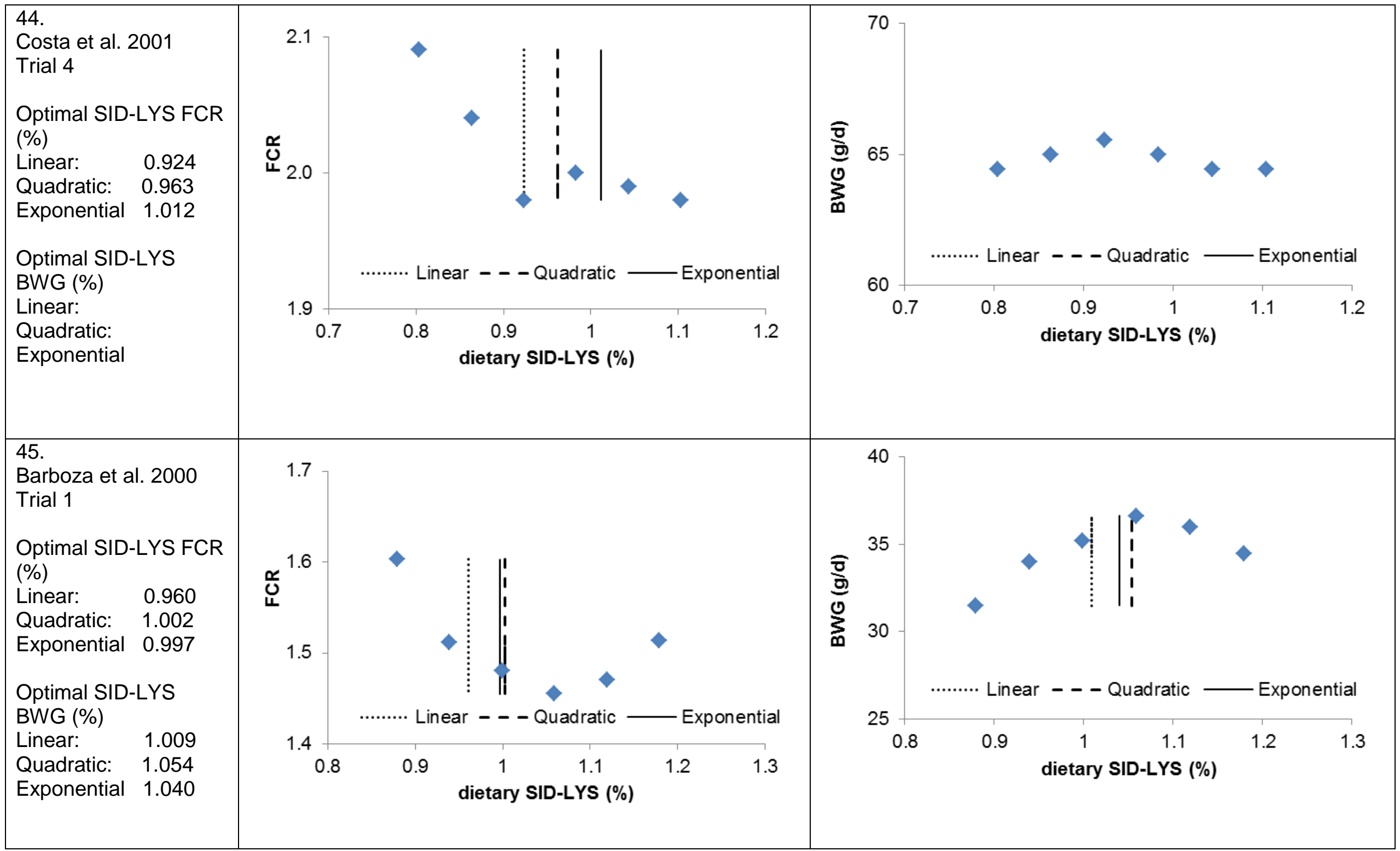




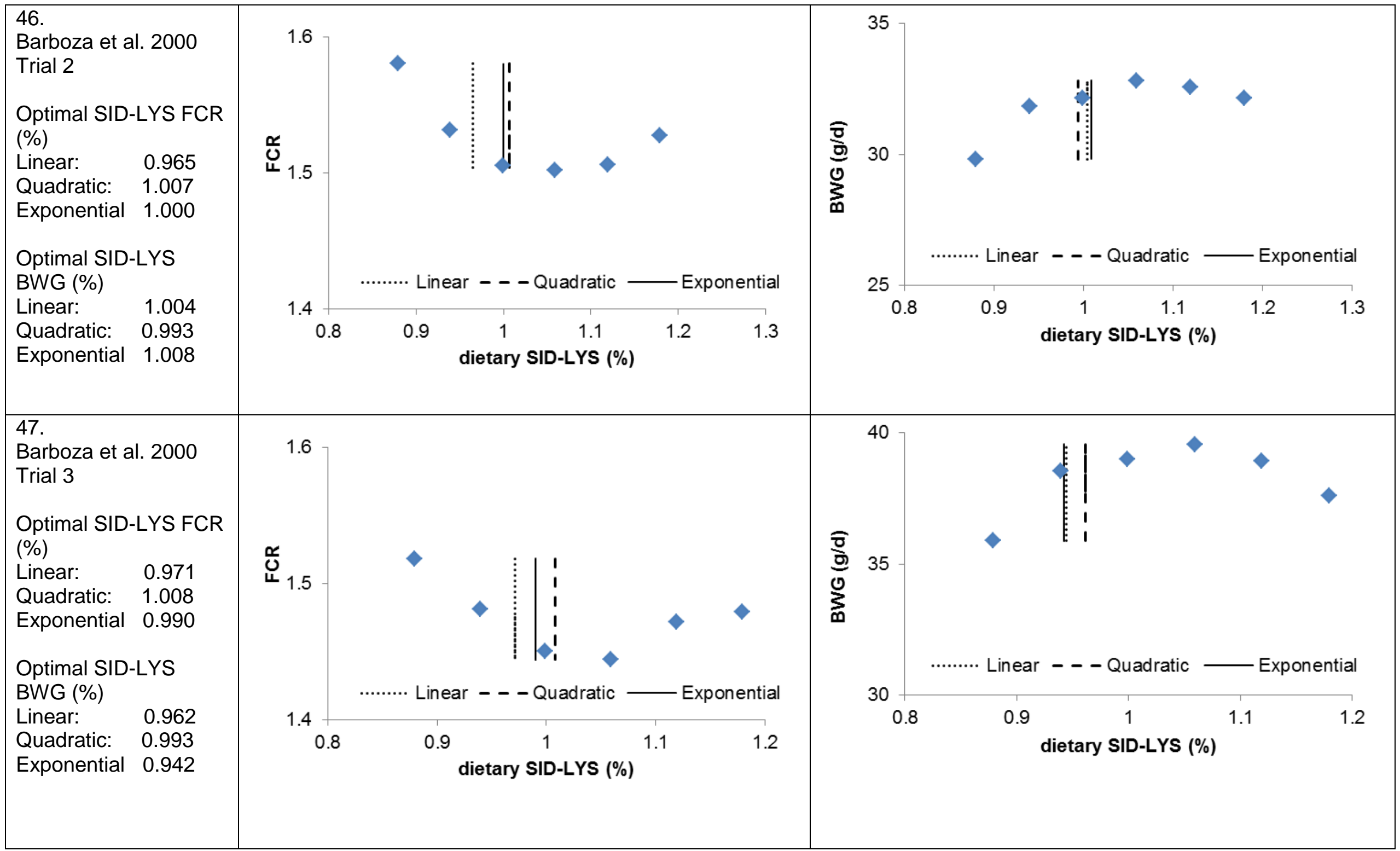




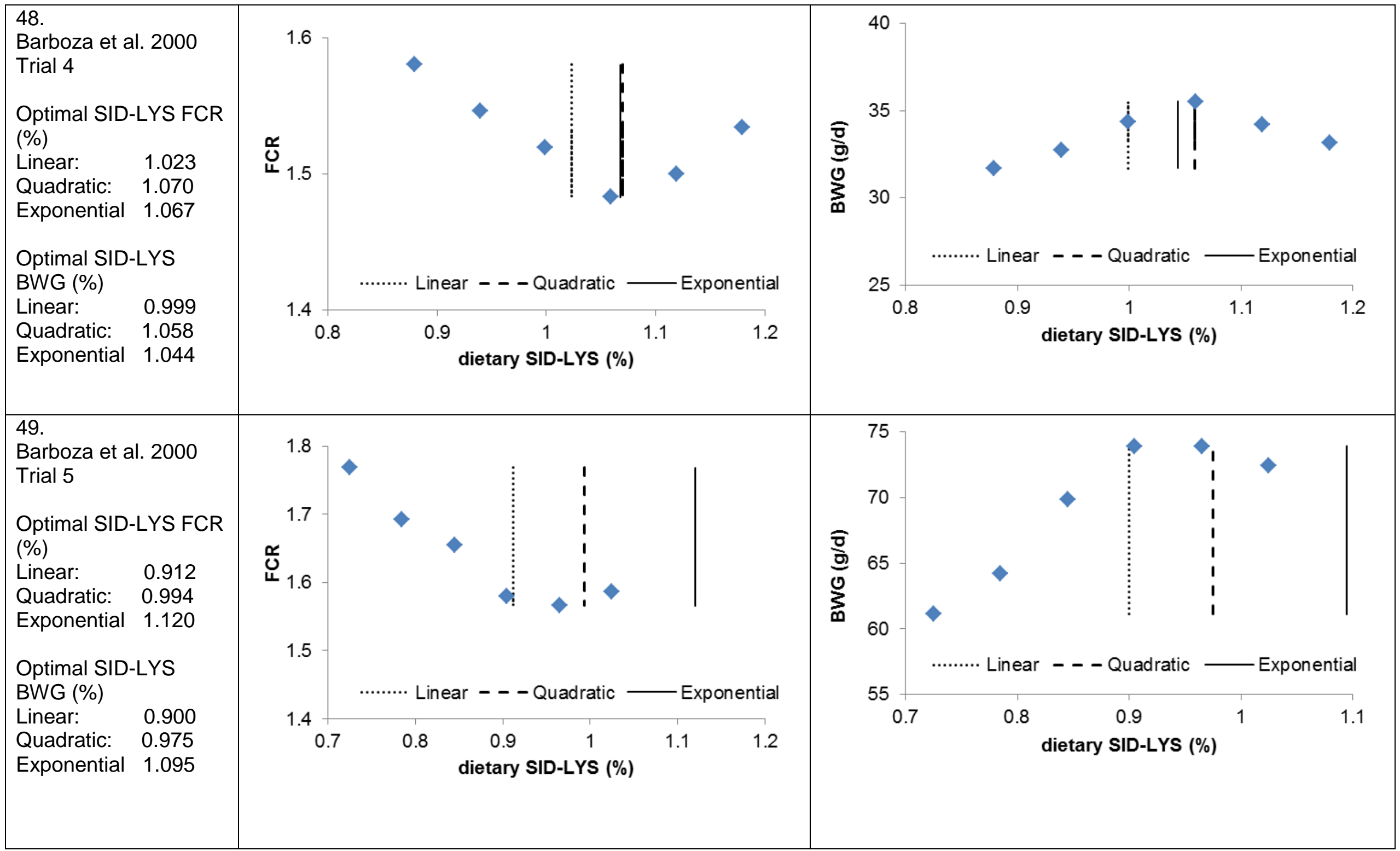




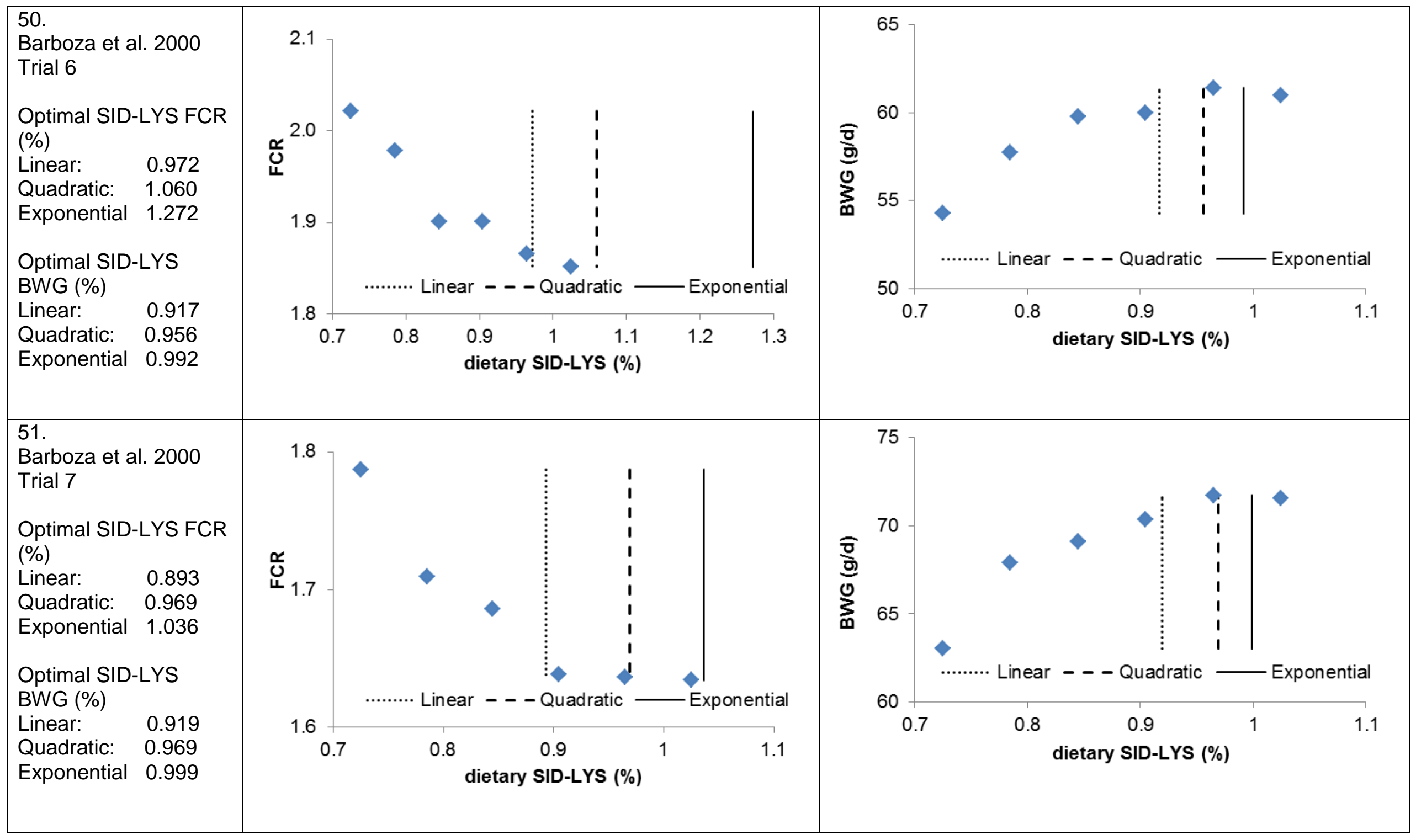




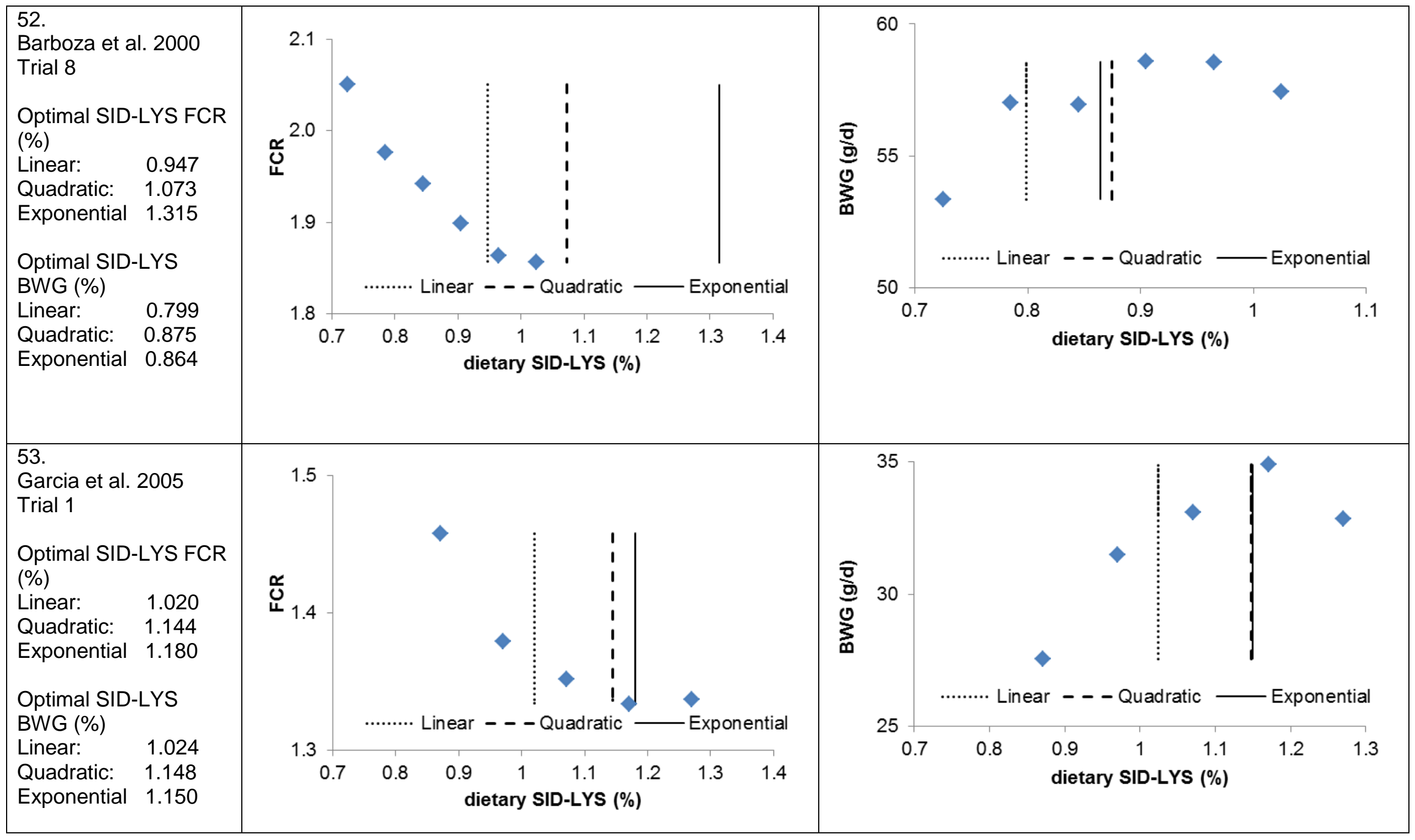




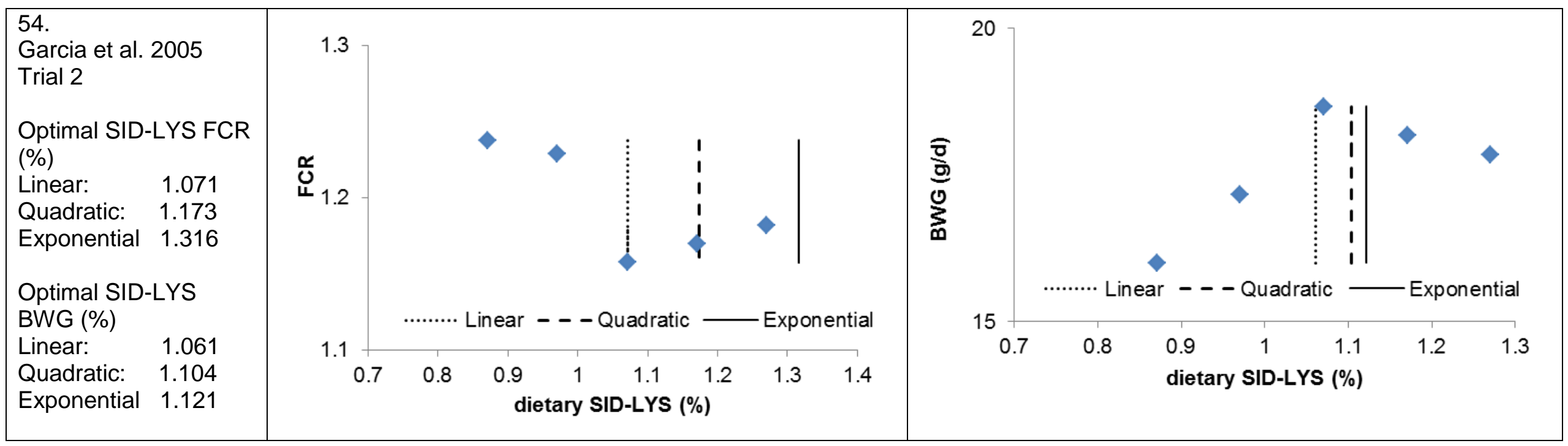




\section{Appendix B. SID-LYS model estimates using the quadratic broken-line model for minimum FCR and maximum BWG}

\begin{tabular}{|c|c|c|c|c|c|c|c|}
\hline Trial nr. & $\begin{array}{r}\text { Estimate } \\
\text { L }\end{array}$ & Std. Err. & $\begin{array}{r}\text { Estimate } \\
\mathbf{R}\end{array}$ & $\begin{array}{r}\text { Std. Err. } \\
\mathbf{R}\end{array}$ & $\begin{array}{r}\text { Estimate } \\
\mathrm{U}\end{array}$ & Std. Err. & $\mathbf{R}^{2}$ \\
\hline 1 & 1.55 & 0.054 & 1.093 & 0.1306 & 3.85 & 3.423 & 0.847 \\
\hline 2 & 1.58 & 0.038 & 1.026 & 0.0574 & 9.61 & 5.036 & 0.945 \\
\hline 3 & 1.53 & 0.033 & 1.023 & 0.1166 & 3.85 & 3.662 & 0.892 \\
\hline 4 & 1.60 & 0.003 & 1.058 & 0.0053 & 4.29 & 0.153 & 1.000 \\
\hline 5 & 1.44 & 0.049 & 1.071 & 0.1455 & 3.40 & 3.419 & 0.865 \\
\hline 6 & 1.62 & 0.004 & 1.043 & 0.0106 & 3.77 & 0.287 & 1.000 \\
\hline 7 & 1.41 & 0.035 & 1.213 & 0.0636 & 3.66 & 1.246 & 0.985 \\
\hline 8 & 1.46 & 0.021 & 1.119 & 0.0549 & 4.49 & 2.014 & 0.971 \\
\hline 9 & 1.46 & 0.151 & 1.285 & 0.3379 & 2.00 & 2.629 & 0.895 \\
\hline 10 & 1.46 & 0.015 & 1.126 & 0.0485 & 3.53 & 1.347 & 0.979 \\
\hline 11 & 1.79 & 0.048 & 1.120 & 0.1330 & 8.87 & 15.414 & 0.725 \\
\hline 12 & 1.40 & 0.007 & 1.248 & 0.0196 & 3.10 & 0.413 & 0.997 \\
\hline 14 & 1.46 & 0.009 & 1.048 & 0.0455 & 1.87 & 0.602 & 0.985 \\
\hline 15 & 1.40 & 0.077 & 1.428 & 0.1005 & 2.06 & 0.521 & 0.997 \\
\hline 16 & 1.49 & 0.007 & 1.090 & 0.0404 & 1.56 & 0.404 & 0.984 \\
\hline 17 & 1.45 & 0.006 & 1.191 & 0.0289 & 1.74 & 0.306 & 0.986 \\
\hline 18 & 1.63 & 0.006 & 1.034 & 0.0394 & 3.44 & 1.630 & 0.913 \\
\hline 19 & 1.22 & 0.010 & 1.396 & 0.0799 & 0.58 & 0.171 & 0.978 \\
\hline 20 & 1.17 & 0.006 & 1.157 & 0.0314 & 1.86 & 0.397 & 0.986 \\
\hline 21 & 1.14 & 0.015 & 1.325 & 0.0755 & 1.13 & 0.391 & 0.965 \\
\hline 22 & 1.05 & 0.007 & 1.067 & 0.0363 & 3.25 & 1.138 & 0.967 \\
\hline 23 & 1.87 & 0.004 & 0.804 & 0.0024 & 86.57 & 4.484 & 1.000 \\
\hline 24 & 1.72 & 0.005 & 1.028 & 0.0521 & 2.68 & 1.893 & 0.977 \\
\hline 25 & 1.75 & 0.000 & 1.085 & 0.0000 & 1.00 & 0.000 & 1.000 \\
\hline 26 & 1.89 & 0.019 & 1.023 & 0.0655 & 1.95 & 0.630 & 0.952 \\
\hline 27 & 1.78 & 0.004 & 1.061 & 0.0126 & 2.77 & 0.199 & 0.998 \\
\hline 28 & 1.72 & 0.003 & 1.005 & 0.0149 & 1.91 & 0.175 & 0.998 \\
\hline 29 & 1.72 & 0.030 & 1.047 & 0.1248 & 1.77 & 1.187 & 0.906 \\
\hline 30 & 1.60 & 0.014 & 1.142 & 0.0879 & 1.26 & 0.670 & 0.939 \\
\hline 31 & 1.39 & 0.011 & 1.080 & 0.0320 & 7.06 & 2.787 & 0.958 \\
\hline 32 & 1.38 & 0.020 & 1.344 & 0.1321 & 0.76 & 0.400 & 0.940 \\
\hline 35 & 1.44 & 0.014 & 0.983 & 0.0323 & 8.36 & 2.467 & 0.985 \\
\hline 36 & 1.43 & 0.019 & 1.104 & 0.0556 & 3.24 & 1.076 & 0.977 \\
\hline 37 & 1.60 & 0.003 & 1.018 & 0.0159 & 2.79 & 0.371 & 0.998 \\
\hline 38 & 1.60 & 0.010 & 0.961 & 0.0253 & 8.29 & 2.322 & 0.990 \\
\hline 39 & 1.43 & 0.004 & 1.033 & 0.0236 & 3.48 & 1.137 & 0.986 \\
\hline 40 & 1.83 & 0.015 & 0.868 & 0.0633 & 7.41 & 8.072 & 0.871 \\
\hline 41 & 1.38 & 0.013 & 1.162 & 0.0532 & 2.37 & 0.954 & 0.965 \\
\hline 42 & 1.40 & 0.009 & 1.100 & 0.0418 & 3.47 & 1.492 & 0.962 \\
\hline 43 & 1.87 & 0.005 & 1.018 & 0.0196 & 3.66 & 0.684 & 0.992 \\
\hline 44 & 1.99 & 0.008 & 0.963 & 0.0417 & 4.18 & 2.273 & 0.942 \\
\hline 45 & 1.48 & 0.013 & 1.002 & 0.0556 & 8.16 & 7.679 & 0.866 \\
\hline 46 & 1.51 & 0.006 & 1.007 & 0.0470 & 4.32 & 3.299 & 0.909 \\
\hline 47 & 1.46 & 0.009 & 1.008 & 0.0862 & 3.45 & 4.787 & 0.750 \\
\hline 48 & 1.51 & 0.013 & 1.070 & 0.1097 & 2.07 & 2.467 & 0.767 \\
\hline 49 & 1.57 & 0.014 & 0.994 & 0.0495 & 2.72 & 0.981 & 0.972 \\
\hline 50 & 1.85 & 0.021 & 1.060 & 0.0884 & 1.53 & 0.713 & 0.967 \\
\hline 51 & 1.63 & 0.007 & 0.969 & 0.0340 & 2.50 & 0.706 & 0.982 \\
\hline 52 & 1.85 & 0.013 & 1.073 & 0.0458 & 1.62 & 0.366 & 0.993 \\
\hline 53 & 1.34 & 0.004 & 1.144 & 0.0307 & 1.60 & 0.363 & 0.992 \\
\hline 54 & 1.17 & 0.018 & 1.173 & 0.2150 & 0.80 & 1.158 & 0.757 \\
\hline
\end{tabular}


SID-LYS model estimates using the quadratic broken-line model for maximum BWG

\begin{tabular}{|c|c|c|c|c|c|c|c|}
\hline Trial nr. & $\begin{array}{r}\begin{array}{r}\text { Estimate } \\
\mathrm{L}\end{array} \\
\end{array}$ & $\begin{array}{r}\text { Std. Err. } \\
\text { L }\end{array}$ & $\begin{array}{r}\text { Estimate } \\
\mathbf{R} \\
\end{array}$ & $\begin{array}{r}\text { Std. Err. } \\
\mathbf{R}\end{array}$ & $\begin{array}{r}\text { Estimate } \\
\mathbf{U}\end{array}$ & $\begin{array}{r}\text { Std. Err. } \\
\text { U }\end{array}$ & $\mathbf{R}^{2}$ \\
\hline 1 & 185 & 3.1 & 1.040 & 0.0549 & -738 & 345.0 & 0.954 \\
\hline 2 & 149 & 3.4 & 1.034 & 0.0547 & -849 & 406.6 & 0.953 \\
\hline 3 & 45 & 2.3 & 1.090 & 0.1312 & -162 & 135.8 & 0.906 \\
\hline 4 & 45 & 0.4 & 1.034 & 0.0208 & -223 & 34.5 & 0.998 \\
\hline 6 & 42 & 0.5 & 0.954 & 0.0310 & -304 & 105.1 & 0.992 \\
\hline 7 & 47 & 1.3 & 1.151 & 0.0635 & -188 & 83.1 & 0.972 \\
\hline 8 & 42 & 1.0 & 1.096 & 0.0390 & -347 & 122.2 & 0.982 \\
\hline 9 & 41 & 1.2 & 1.125 & 0.0816 & -171 & 109.8 & 0.943 \\
\hline 10 & 39 & 1.2 & 1.044 & 0.0678 & -373 & 299.5 & 0.929 \\
\hline 12 & 42 & 0.7 & 1.193 & 0.0451 & -208 & 82.6 & 0.976 \\
\hline 14 & 39 & 0.3 & 0.908 & 0.0232 & -422 & 145.6 & 0.986 \\
\hline 16 & 75 & 0.2 & 1.035 & 0.0217 & -127 & 21.5 & 0.994 \\
\hline 17 & 83 & 0.6 & 1.124 & 0.0351 & -195 & 53.8 & 0.966 \\
\hline 18 & 67 & 0.5 & 0.983 & 0.0891 & -222 & 328.4 & 0.545 \\
\hline 19 & 29 & 0.1 & 1.213 & 0.0161 & -71 & 7.5 & 0.997 \\
\hline 20 & 33 & 0.3 & 1.079 & 0.0304 & -173 & 48.3 & 0.978 \\
\hline 21 & 22 & 0.1 & 1.294 & 0.0180 & -38 & 3.5 & 0.997 \\
\hline 22 & 22 & 0.2 & 1.163 & 0.0438 & -56 & 16.6 & 0.974 \\
\hline 23 & 31 & 0.2 & 0.815 & 0.0067 & -1273 & 166.8 & 0.997 \\
\hline 24 & 98 & 0.3 & 1.064 & 0.1164 & -54 & 69.5 & 0.900 \\
\hline 26 & 94 & 0.8 & 0.944 & 0.0423 & -172 & 45.2 & 0.969 \\
\hline 27 & 104 & 0.7 & 1.014 & 0.0368 & -208 & 50.8 & 0.974 \\
\hline 28 & 84 & 0.3 & 0.923 & 0.0187 & -252 & 39.2 & 0.995 \\
\hline 29 & 77 & 0.2 & 0.864 & 0.0196 & -222 & 47.3 & 0.992 \\
\hline 30 & 62 & 0.9 & 1.083 & 0.0976 & -100 & 72.8 & 0.896 \\
\hline 31 & 38 & 0.5 & 1.111 & 0.0549 & -135 & 77.2 & 0.907 \\
\hline 32 & 33 & 0.2 & 1.172 & 0.0642 & -35 & 15.0 & 0.962 \\
\hline 33 & 32 & 0.3 & 1.135 & 0.1703 & -23 & 29.6 & 0.737 \\
\hline 34 & 21 & 0.3 & 1.148 & 0.0693 & -49 & 25.6 & 0.945 \\
\hline 35 & 31 & 0.3 & 1.058 & 0.0346 & -99 & 23.7 & 0.988 \\
\hline 36 & 33 & 1.0 & 1.204 & 0.0962 & -66 & 28.7 & 0.957 \\
\hline 37 & 59 & 0.3 & 0.925 & 0.0286 & -351 & 133.9 & 0.986 \\
\hline 38 & 61 & 0.6 & 0.970 & 0.0434 & -291 & 134.1 & 0.974 \\
\hline 39 & 29 & 0.2 & 1.006 & 0.0552 & -146 & 140.2 & 0.896 \\
\hline 40 & 65 & 0.6 & 0.917 & 0.0709 & -140 & 118.9 & 0.902 \\
\hline 41 & 35 & 0.2 & 1.156 & 0.0300 & -78 & 18.3 & 0.988 \\
\hline 42 & 32 & 0.1 & 1.040 & 0.0302 & -114 & 50.6 & 0.965 \\
\hline 43 & 83 & 0.5 & 0.953 & 0.0413 & -298 & 170.0 & 0.940 \\
\hline 45 & 36 & 0.5 & 1.054 & 0.0751 & -135 & 121.6 & 0.849 \\
\hline 46 & 32 & 0.2 & 0.993 & 0.0317 & -199 & 115.0 & 0.944 \\
\hline 47 & 39 & 0.4 & 0.962 & 0.0663 & -426 & 682.1 & 0.765 \\
\hline 48 & 34 & 0.6 & 1.058 & 0.1289 & -86 & 129.4 & 0.664 \\
\hline 49 & 73 & 1.1 & 0.975 & 0.0582 & -211 & 98.8 & 0.952 \\
\hline 50 & 61 & 0.4 & 0.956 & 0.0368 & -122 & 39.7 & 0.976 \\
\hline 51 & 71 & 0.5 & 0.969 & 0.0436 & -134 & 48.6 & 0.970 \\
\hline 52 & 58 & 0.5 & 0.875 & 0.0598 & -200 & 164.4 & 0.882 \\
\hline 53 & 34 & 0.7 & 1.148 & 0.0994 & -81 & 58.7 & 0.927 \\
\hline 54 & 18 & 0.3 & 1.104 & 0.1172 & -41 & 41.9 & 0.886 \\
\hline
\end{tabular}

